\title{
THE CONGO DEEP-SEA FAN: MINERALOGICAL, REE, AND ND-ISOTOPE VARIABILITY IN QUARTZOSE PASSIVE-MARGIN SAND
}

\author{
EDUARDO GARZANTI, ${ }^{1}$ GERMAIN BAYON,${ }^{2}$ BERNARD DENNIELOU,${ }^{2}$ MARTA BARBARANO, ${ }^{1}$ MARA LIMONTA, ${ }^{1}$ AND GIOVANNI \\ VEZZOLI $^{1}$ \\ ${ }^{1}$ Laboratory for Provenance Studies, Department of Earth and Environmental Sciences, University of Milano-Bicocca, 20126 Milano, Italy \\ ${ }^{2}$ Unité de Recherche Geosciences Marines, Ifremer, CS 10070, 29280 Plouzané, France \\ e-mail: eduardo.garzanti@unimib.it
}

\begin{abstract}
The Congo deep-sea fan, the largest on Earth fed entirely with anorogenic detritus, is characterized by quartzose to pure quartzose sand, reflecting multiple recycling coupled with extreme chemical weathering in cratonic equatorial Africa. The very youthful lower course of the Congo River connects directly to a steep canyon, where detritus including quartz grains up to a few millimeters in diameter is funneled towards Atlantic Ocean floors and deposited at abyssal depths more than a thousand kilometers away from shore. This article illustrates for the first time in detail the mineralogical and geochemical signatures of Congo Fan sands and discusses the factors controlling their intersample and intrasample variability as a key to understand how sediment is generated, recycled, and finally transferred to the deep sea. Compositional variability is largely grain-size-dependent. Combined petrographic and Raman spectroscopy analyses demonstrate that quartz increases in coarser samples and size classes, whereas feldspars are concentrated in finer sizes, plagioclase relative to $\mathrm{K}$-feldspar and orthoclase relative to microcline, defining an order of mechanical and chemical durability among detrital tectosilicates. Because of overwhelming quartz abundance and very low heavy-mineral concentration, quartz contributes significantly to the REE budget and up to $40-50 \%$ of $\mathrm{Nd}$ in coarser samples, characterized by $\varepsilon_{\mathrm{Nd}}$ values as low as -21 . The strong grain-size-dependent variability of $\varepsilon_{\mathrm{Nd}}$ suggests that quartz carries a markedly more negative $\varepsilon_{\mathrm{Nd}}$ signature than monazite and other detrital components. This is chiefly ascribed to the durability of quartz grains, able to survive repeated cycles of weathering and diagenesis through Proterozoic and Phanerozoic time better than all other minerals. Neodymium model ages are influenced less by grain size and quartz abundance but more by the $\mathrm{Sm} / \mathrm{Nd}$ ratio of different detrital components, and samples hydrodynamically enriched in LREE-rich minerals display $\mathbf{T}_{\mathrm{Nd}, \mathrm{CHUR}}$ and $\mathbf{T}_{\mathrm{Nd}, \mathrm{DM}}$ ages $1.2-$ 1.4 Ga younger than samples enriched in HREE minerals.

Not all detritus in the Congo Fan is supplied transversally by the Congo River. Forward-mixing calculations based on mineralogical data indicate that sand entrained northward by longshore currents mixes progressively with Congo River sand along the northernmost Angola coast, penetrates in the Soyo estuary, and is eventually captured in the canyon and transferred to the deep-sea fan, where it is estimated to represents $7 \pm 2 \%$ of turbidite deposits.
\end{abstract}

"He who knows all the answers has not been asked all the questions." Kong Fu Zi (Confucius)

\section{INTRODUCTION}

Large deep-sea fans are long-lived depositional systems generally connected to, and fed from, a major river mouth. They thus represent rich natural archives that quasi-continuously recorded environmental signals from the adjacent continent (Hessler and Fildani 2019). The careful scrutiny of compositional signatures preserved in the sedimentary record and the full comprehension of their meaning potentially allow us to gain insight on how the interplay between tectonics and climate has driven landscape changes across vast continental areas in the recent and less recent past (e.g., Revel et al. 2014; Clift 2017; Hein et al. 2017; Fierens et al. 2020). In turn, reconstructing geological and geomorphological processes through time can allow us to better tune long-term models aimed at understanding how climate has both evolved in the past and will evolve in the future, and its impact on erosion rates, sediment production, vegetation cover, and the carbon cycle (e.g., Galy et al. 2011; Wagner et al. 2014; Feakins et al. 2020). This is particularly true for a critical region hosting a vast equatorial rain forest such as the Congo (Weijers et al. 2009; Schefuß et al. 2016; Rabouille et al. 2019).

The Congo sediment-routing system is unique on Earth. The large river that lazily drains the continental interiors of central Africa suddenly dashes with the impetuosity of a mountain torrent in its final tract, along a series of rapids and falls separating Kinshasa the capital of DR Congo from the port of Matadi (Fig. 1; Runge 2007). The Congo River has no delta, but $\sim 30 \mathrm{~km}$ before reaching the coast it connects directly to a large canyon that funnels quartz-rich detritus up to granule size for more than $1000 \mathrm{~km}$ into the abysses of Atlantic Ocean floors. The youthfulness of such an extraordinary river profile, cut across a passive margin originated more than a hundred million years ago, still needs full understanding. 


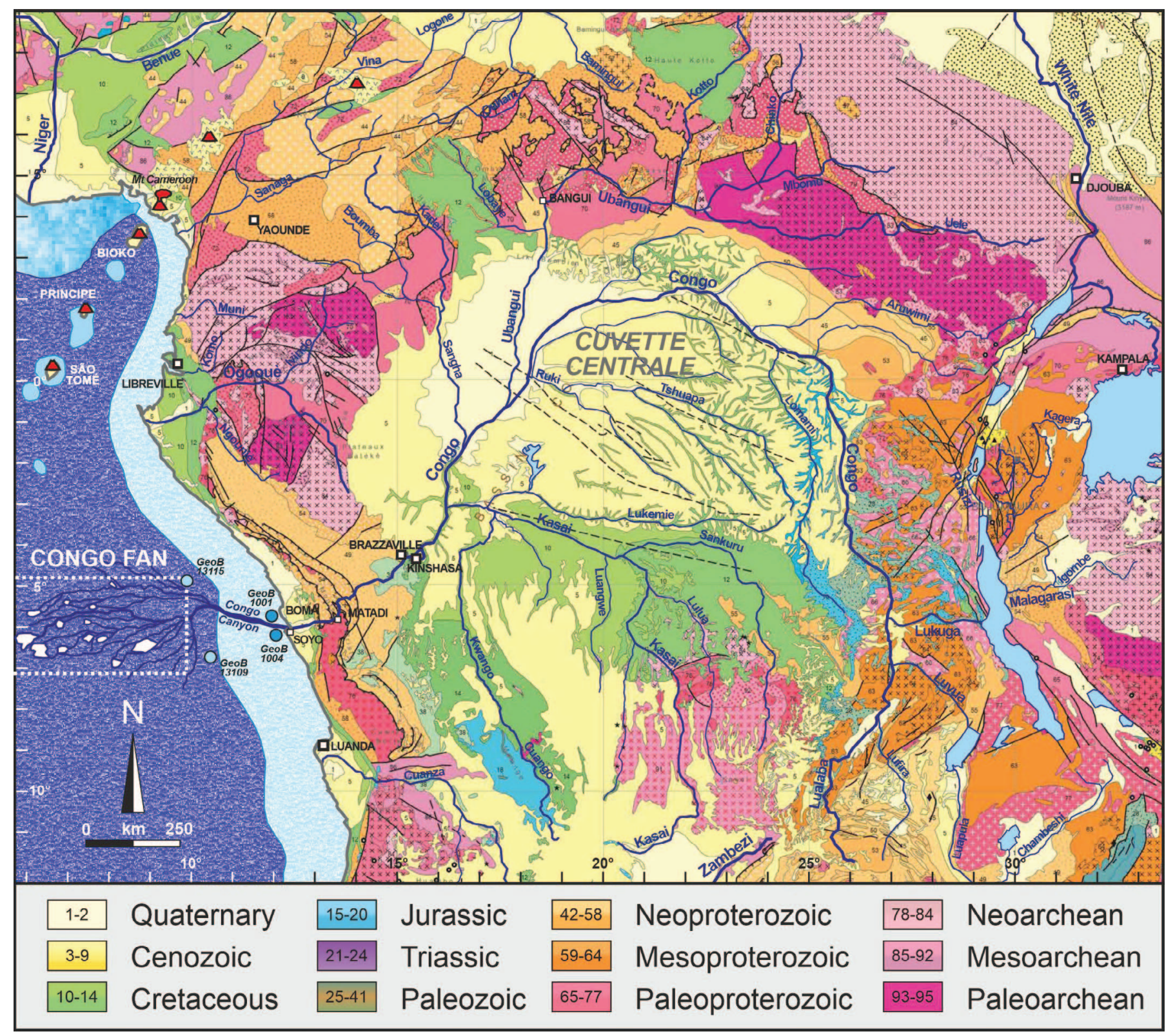

FIG. 1.-Geological map of the Congo catchment (modified after CGMW-BRGM 2016). The white dotted rectangle outlines the inner and middle Congo Fan, including part of the study area enlarged in Figure 2A. Fan channels and lobes are drawn after Droz et al. (2003) and Marsset et al. (2009). Location of offshore samples collected on both sides of the Congo Canyon are also shown.

The present study investigates the mineralogical and geochemical composition of Congo Fan sediments as a key to unravel the processes controlling sediment generation, transport, and deposition in such an exceptional natural setting. Sand of the Congo River and fan is the richest in quartz of all large source-to-sink systems on Earth (McLennan et al. 1990), reflecting extensive recycling coupled with extreme weathering conditions in cratonic equatorial Africa (Gaillardet et al. 1995; Dupré et al. 1996; Dinis et al. 2020). Detailed analyses of mineralogical and geochemical variability have been carried out on modern glacial, fluvial, eolian, or beach sediments (e.g., Whitmore et al. 2004; Garzanti et al. 2015a; von Eynatten et al. 2012, 2016), but only seldom on deep-sea fans, which have been mineralogically well studied particularly for arc-trench systems and remnant-ocean basins (e.g., Ingersoll and Suczek 1979; Marsaglia and Ingersoll 1992; Shapiro et al. 2007; Pickering et al. 2020) but not equally systematically so far in passive-margin settings (e.g., Thayer et al. 1986; Marsaglia et al. 1996; Hessler et al. 2018). The present article, which builds on a previous provenance study focused on the Congo River system (Garzanti et al. 2019a), contributes to fill this gap by documenting for the first time in detail the compositional fingerprints of sediments in the largest deep-sea fan on Earth fed entirely with anorogenic cratonic detritus.

Because of overwhelming quartz abundance and limited spectrum of major detrital components, the Congo Fan may seem a poorly suited place for a detailed analysis of compositional variability. Hydrodynamic sorting is generally at minimum in abyssal environments, where depositional processes are dominant and local reworking by bottom currents virtually nil. However, this may not be true for the studied along-channel-axis deposits, because sediment transport in the deeply entrenched channel may 
occur stepwise in bedload mode under the action of tractive currents (Babonneau et al. 2002). Such a peculiar case thus provides an excellent opportunity to assess grain-size control on mineralogical and geochemical parameters, to investigate the role played by hydraulic sorting in the deep sea, how the diverse detrital minerals impact on the geochemical budget and in which proportion they contribute to rare earth elements (REE) patterns, and eventually to unravel the multiple geological causes of grainsize-dependent compositional variability.

\section{THE CONGO SEDIMENT-ROUTING SYSTEM}

\section{The River}

The 4700-km-long Congo River, the ninth-longest on Earth, is second only to the Amazon in drainage area $\left(3.7 \cdot 10^{6} \mathrm{~km}^{2}, 12 \%\right.$ of Africa, $\sim 2.2 \%$ of the Earth's land surface) and water flux (mean $41,000 \mathrm{~m}^{3} / \mathrm{s}$; Laraque et al. 2009). The major headwater branch is the Lualaba and the two major tributaries are the Kasai from the south and the Ubangui (Oubangui) from the north (Fig. 1). Peak discharge is recorded around December, after receiving the rainy-season runoff from northern tributaries; a smaller peak fed from southern tributaries occurs around May. The relatively low suspended-sediment load is estimated as $\sim 30$. $10^{6} \mathrm{t} / \mathrm{a}\left(\sim 810^{6} \mathrm{t}\right.$ of which very fine sand, $\geq 20 \cdot 10^{6} \mathrm{t}$ silt and clay, $\leq 3$. $10^{6} \mathrm{t}$ organic matter; Laraque et al. 2009), corresponding to an annual sediment yield of $\leq 10 \mathrm{t} \mathrm{km}^{-2}$.

Bedload fluxes, however, are unknown, and suspended-load estimates mostly range from 31 to $65 \cdot 10^{6} \mathrm{t} / \mathrm{a}$, which would imply an average annual sediment yield of $10-15 \mathrm{t} \mathrm{km}^{-2}$ if bedload represents $5-10 \%$ of suspended load (Hay 1998; Milliman and Farnsworth 2013 p. 24). By assuming an average source-rock density of $2.66-2.67 \mathrm{~g} / \mathrm{cm}^{3}$, based on our own mineralogical data, erosion rates averaged across the vast catchment are assessed as $\sim 0.005 \mathrm{~mm} / \mathrm{a}$. If $\sim 10 \%$ of the sediment is generated in the juvenile tract downstream of Kinshasa (Garzanti et al. 2019a), then erosion rates would be five times higher in this only $80,000-\mathrm{km}^{2}$-wide area than in the vast catchment upstream (i.e., $\sim 0.02 \mathrm{~mm} / \mathrm{a}$ vs. $0.004 \mathrm{~mm} / \mathrm{a}$ ).

The Congo drainage basin, straddling the Equator from $\sim 13^{\circ} \mathrm{S}$ to $\sim 9^{\circ}$ $\mathrm{N}$ (Fig. 1), is delimited by the late Mesozoic Central African rift system to the north, by the mid-Cenozoic East African rift system to the east, and by the Kalahari Plateau to the south (Leturmy et al. 2003). Exposed in the vast catchment are diverse Archean cratonic blocks (Ntem and MbomuUganda in the north; Kwango and Kasai in the south), surrounded by Paleoproterozoic (Eburnean) fold belts, domains affected by Mesoproterozoic intrusions (e.g., Kibaran belt in the east), and Pan African fold belts (e.g., Lufilian arc in the south) (for a more extensive summary of rock complexes drained by the Congo River the reader is referred to Garzanti et al. 2019a). The central part of the basin (cuvette centrale), a wide depression accounting for $\sim 30 \%$ of the entire catchment, is characterized by an equatorial climate with 2.0-2.3 m of annual rainfall (Alsdorf et al. 2016). The juvenile lower course begins downstream of Kinshasa, where the river drops by $\sim 270 \mathrm{~m}$ over $\sim 350 \mathrm{~km}$ across the Atlantic Rise. This very steep tract is characterized by the deepest fluvial channel on Earth $(\geq$ $220 \mathrm{~m}$; Oberg et al. 2009) and by the deadliest rapids where water rushes at $14 \mathrm{~m} / \mathrm{s}$ and waves reach up to $12 \mathrm{~m}$ in height. There is no consensus whether these extremely youthful features have resulted from capture by a short headward-eroding coastal stream (Goudie 2005) or by recent uplift of an antecedent river (Flügel et al. 2015), and whether the Congo River outlet has remained fixed since the Late Cretaceous (Anka et al. 2010; Linol et al. 2015) or was established in the Oligocene (Karner and Driscoll 1999; Savoye et al. 2000), mid-Miocene (Uenzelmann-Neben 1998), or only very recently in the early Pleistocene (Peters and O'Brien 2001; Giresse 2005).

The $\sim 130$-km-long, navigable final stretch of the river downstream of Matadi is initially narrow, deeply incised, and characterized by huge whirlpools. The wide Soyo estuary eventually opens up downstream of Boma, with an average tidal range of $1.4 \mathrm{~m}$ (Bultot 1971).

\section{The Canyon and the Fan}

Within the estuary $\sim 30 \mathrm{~km}$ upstream of the mouth, the Congo river channel deepens and transforms into a submarine valley directly connected to a steep canyon entrenched into the continental shelf. As a consequence, the Congo River has no subaerial delta and virtually its entire bedload reaching the sea is ultimately transferred directly by gravity flows to the large deep-sea fan, as documented by repeated cable breaks in the canyon coinciding with periods of peak water and sediment discharge (Heezen et al. 1964; Anka et al. 2009; Babonneau et al. 2010). Frequent and powerful mud-rich turbidity flows, possibly triggered by slope instability, are prolonged over several days to a full week. Active turbiditic sedimentation during the current interglacial highstand is a peculiar feature that distinguishes the Congo from the other major rivers on Earth (Babonneau et al. 2002). Sediment transport is of the same order of magnitude as the discharge of the Congo River, and involves an estimated $\sim 2 \%$ of the total terrestrial organic carbon buried annually in the world's oceans (AzpirozZabala et al. 2017).

The deeply entrenched Congo canyon, lying $480 \mathrm{~m}$ b.s.l. at the river mouth and $\sim 1000 \mathrm{~m}$ b.s.l. at the shelf edge, continues into a meandering channel over a cumulative length of $1135 \mathrm{~km}$ from the estuary to the fan lobes (Savoye et al. 2000). Congo turbidites are thus traced for more than a thousand kilometers, whereas during hypopycnal flows the sediment-laden surface plume can be followed for $20 \mathrm{~km}$ and the freshwater plume to as far as $800 \mathrm{~km}$ offshore (Eisma and Kalf 1984; Braga et al. 2004; Denamiel et al. 2013).

The steep trench carved by the Congo River across the entire width of the western African continental margin from the Atlantic Rise to the deepsea is a unique geomorphic feature, the origin, causal mechanisms, and evolution of which are still poorly understood (Ferry et al. 2004; Anka et al. 2010). Diverse and complexly interplaying factors controlling the balance between erosion and sedimentation have been called upon, including tectonic activity and climatic, eustatic, and oceanographic changes (McGinnis et al. 1993; Lavier et al. 2001; Lucazeau et al. 2003; Séranne and Anka 2005). A positive feedback of fluvial incision and canyon cutting followed by erosional unloading, possibly initiated with dynamic uplift of Africa and climate change in the Oligocene, may have culminated with capture of the vast endorheic Congo catchment by a headward-eroding coastal stream. Submarine erosion, related either to gravity flows triggered by sediment overload and failure at the head and flanks of the canyon or to hyperpycnal currents generated by fluvial floods and enhanced further during Pleistocene glacio-eustatic lowstands, has remained active up to today (Shepard and Emery 1973; Savoye et al. 2009; Dennielou et al. 2017).

\section{SAMPLING AND ANALYTICAL METHODS}

For this study we have selected 15 upper Pleistocene to recent sediment samples of the Congo Fan from 15 different cores retrieved during cruises ZAIANGO1 (Savoye 1998), ZAIANGOROV (Savoye and Ondréas 2000), REPREZAI_LEG1 (Marsset and Droz 2010), and CONGOLOBE (Rabouille 2011) (Table 1). Cores were collected by piston corer at water depths between -3709 and $-4942 \mathrm{~m}$ b.s.l. in active channels ( 8 samples), lobe distributary channels ( 3 samples), and abandoned channels and lobes (2 samples each) (Fig. 2; Marsset et al. 2009; Dennielou et al. 2017; Picot et al. 2019). Full information on sampling sites is provided in Appendix Table A1. The grain-size distribution of each sample was determined by both sieving and laser granulometry (textural parameters provided in Appendix Table A2); median and maximum diameters were measured also 
TABLE 1.-Information on the 15 studied sediment samples and sample availability.

\begin{tabular}{|c|c|c|c|c|c|c|c|}
\hline Sample & Cruise & Core & Core Depth (m b.s.f.) & Depth (m b.s.1.) & Age & Facies & International Geo Sample Number \\
\hline 5851 & ZAIANGOROV & KZR-06 & $590-592$ & 4942 & $<4.6 \mathrm{ka} \mathrm{BP}$ & Active channel & http://igsn.org/BFBGX-86495 \\
\hline 5852 & ZAIANGOROV & KZR-10 & $160-162$ & 4835 & $<4.6 \mathrm{ka} \mathrm{BP}$ & Lobe distributary & http://igsn.org/BFBGX-86500 \\
\hline 5853 & CONGOLOBE & COL-F-CS03 & $910-912$ & 4866 & $<4.6 \mathrm{ka} \mathrm{BP}$ & Active channel & http://igsn.org/BFBGX-54262 \\
\hline 5854 & ZAIANGOROV & KZR-16 & $909-913$ & 4211 & $4.6-11 \mathrm{ka} \mathrm{BP}$ & Abandoned lobe & http://igsn.org/BFBGX-86492 \\
\hline 5855 & ZAIANGOROV & KZR-21 & $160-162$ & 3709 & & Active channel & http://igsn.org/BFBGX-86498 \\
\hline 5856 & ZAIANGO1 & KZAI-11 & $720-722$ & 4833 & $<4.6 \mathrm{ka} \mathrm{BP}$ & Lobe distributary & http://igsn.org/BFBGX-86521 \\
\hline 5857 & ZAIANGOROV & KZR-15 & $215-219$ & 4525 & & Active channel & http://igsn.org/BFBGX-86491 \\
\hline 5858 & ZAIANGOROV & KZR-11 & $150-152$ & 4779 & & Active channel & http://igsn.org/BFBGX-86493 \\
\hline 5859 & REPREZAI_LEG1 & RZCS-06 & $943-945$ & 4163 & $40 \mathrm{ka}$ & Abandoned channel & http://igsn.org/BFBGX-86917 \\
\hline 5860 & ZAIANGO1 & KZAI-06 & $180-182$ & 4150 & & Active channel & http://igsn.org/BFBGX-86526 \\
\hline 5861 & ZAIANGOROV & KZR-02 & $815-819$ & 4667 & ca $780 \mathrm{ka}$ & Abandoned channel & http://igsn.org/BFBGX-86496 \\
\hline 5862 & REPREZAI_LEG1 & RZCS-07 & $933-935$ & 4166 & $40-70 \mathrm{ka}$ & Abandoned lobe & http://igsn.org/BFBGX-86918 \\
\hline 5863 & ZAIANGO1 & KZAI-07 & $130-134$ & 4934 & $<4.6 \mathrm{ka} \mathrm{BP}$ & Active channel & http://igsn.org/BFBGX-86518 \\
\hline 5864 & ZAIANGO1 & KZAI-12 & $400-405$ & 4813 & $<4.6 \mathrm{ka} \mathrm{BP}$ & Lobe distributary & http://igsn.org/BFBGX-86520 \\
\hline 5865 & ZAIANGO1 & KZAI-15 & $85-193$ & 4433 & & Active channel & http://igsn.org/BFBGX-86517 \\
\hline
\end{tabular}

in thin section using in-house standards of $\phi / 4$ classes prepared by sieving for visual comparison.

New data obtained in the present study will be compared with petrographic and heavy-mineral data obtained during previous provenance studies focused on coastal Angola and on the Congo River system (Garzanti et al. 2018a, 2019a).

\section{Petrography}

Petrographic analysis was carried out by counting 450 points in thin section under the microscope following the Gazzi-Dickinson method (Ingersoll et al. 1984). Sand classification was based on the relative abundance of the three main framework components quartz (Q), feldspars (F), and lithic fragments (L). Subtle distinctions are essential to discriminate among lithic-poor suites $(\mathrm{L}<10 \% \mathrm{QFL})$ deposited along passive continental margins in different tectonic and climatic settings (Dickinson 1985; Garzanti et al. 2001, 2014a). Feldspar-rich feldspathoquartzose $(1<\mathrm{Q} / \mathrm{F}<2)$, feldspatho-quartzose $(2<\mathrm{Q} / \mathrm{F}<4)$, quartz-rich feldspatho-quartzose $(4<\mathrm{Q} / \mathrm{F}<9)$, quartzose $(90 \%<\mathrm{Q} / \mathrm{QFL}<95 \%)$, and pure quartzose compositions $(\mathrm{Q} / \mathrm{QFL}>95 \%)$ are thus distinguished (classification scheme after Garzanti 2019). Petrographic parameters used in this article include the $\mathrm{Q} / \mathrm{F}, \mathrm{P} / \mathrm{F}(\mathrm{P}=$ plagioclase), and Mic*/F (Mic* $=$ microcline with cross-hatch twinning) ratios.

\section{Raman Analyses of Tectosilicates}

Mineralogical analyses on samples 5853, 5854, and 5859, too finegrained to obtain precise quantitative data under the petrographic microscope, were carried out by Raman counting (Andò et al. 2011) on the low-density $\left(<2.90 \mathrm{~g} / \mathrm{cm}^{3}\right)$ fraction subdivided for each sample into five classes obtained by sieving (5-32 mm, 32-63 mm, 63-125 mm, $125-$ $250 \mathrm{~mm}$, and $250-500 \mathrm{~mm}$ ). Detrital tectosilicates are distinguished by their Raman spectral features. Quartz is most readily identified by intense Raman scattering and main peak at $464 \mathrm{~cm}^{-1}$. Instead, the main peak is observed at $513 \mathrm{~cm}^{-1}$ for K-feldspar, at $506-507 \mathrm{~cm}^{-1}$ for albite, and at 509-511 cm $\mathrm{cm}^{-1}$ for oligoclase, andesine, and labradorite (Freeman et al. 2008). Among K-feldspars, which display another peak at $\sim 748 \mathrm{~cm}^{-1}$, the width of all peaks increases and the total number of vibration modes decreases with increasing disorder in the crystalline structure. Well-ordered triclinic microcline is thus identified by three sharp peaks between 155 $\mathrm{cm}^{-1}$ and $286 \mathrm{~cm}^{-1}$, whereas orthoclase displays only two broader peaks in this frequency region. Data are provided in Appendix Table A3.

\section{Heavy Minerals}

From a split aliquot of the almost $7 \phi$-wide, 5-500 $\mu \mathrm{m}$ size window obtained by wet sieving, heavy minerals were separated by centrifuging in Na-polytungstate $\left(2.90 \mathrm{~g} / \mathrm{cm}^{3}\right)$ and recovered by partial freezing with liquid nitrogen (procedure described in Andò 2020). For each sample, $\geq 200$ transparent heavy minerals were point-counted at appropriate regular spacing to obtain correct volume percentages (Garzanti and Andò 2019). Transparent heavy-mineral assemblages are called for brevity "tHM suites" throughout the text. The ZTR index (sum of zircon, tourmaline, and rutile relative to total transparent heavy minerals; Hubert 1962) expresses the durability of the tHM suite through multiple sedimentary cycles (Garzanti 2017). In all analyzed samples, grain roundness and corrosion features on heavy minerals were assessed following the classification of surface textures in Andò et al. (2012). Significant detrital components are listed in order of abundance (high to low) throughout the text. Data are provided in Appendix Tables A4 and A5.

\section{Geochemistry}

Bulk samples were treated using a sequential leaching procedure for removal of Fe-oxide phases, carbonates, and organic matter (Bayon et al. 2002). Before digestion by alkaline fusion, the resulting residual fraction was cleaned from fine silt and clay particles $(<15 \mu \mathrm{m})$ by low-speed centrifugation (200 rpm). Following Bayon et al. (2009), the concentrations of $\mathrm{Ba}, \mathrm{Y}, \mathrm{Zr}$, Hf, and light and heavy rare earth elements (LREE and HREE) were determined at the Pôle Spectrométrie Océan (PSO) with a Thermo Scientific Element XR sector field ICP-MS, yielding uncertainties better than $10 \%$.

Neodymium isotopes were measured at PSO using a Thermo Scientific Neptune multi-collector ICP-MS, after Nd purification by conventional ion chromatography. Repeated analyses of a JNdi-1 standard solution gave ${ }^{143} \mathrm{Nd} /{ }^{144} \mathrm{Nd}$ of $0.512114 \pm 0.000005(2 \sigma, n=10)$, in full agreement with the recommended value of 0.512115 (Tanaka et al. 2000) and corresponding to an external reproducibility of ca. $\pm 0.10 \varepsilon(2 \sigma)$. Epsilon $\varepsilon_{\mathrm{Nd}(0)}$ values were calculated using ${ }^{143} \mathrm{Nd} /{ }^{144} \mathrm{Nd}=0.512630$ (Bouvier et al. 2008). Neodymium depleted-mantle model ages $\left(\mathrm{T}_{\mathrm{Nd}, \mathrm{DM}}\right)$ were calculated following the approach described in DePaolo (1981), using measured Sm and $\mathrm{Nd}$ concentrations $\left({ }^{147} \mathrm{Sm} /{ }^{144} \mathrm{Nd}=\mathrm{Sm} / \mathrm{Nd} \cdot 0.6049\right)$ and present-day ${ }^{143} \mathrm{Nd} /{ }^{144} \mathrm{Nd}(0.512630)$ and ${ }^{147} \mathrm{Sm} /{ }^{144} \mathrm{Nd}(0.1960)$ chondritic values (Bouvier et al. 2008). All geochemical data are provided in Appendix Table A6. 

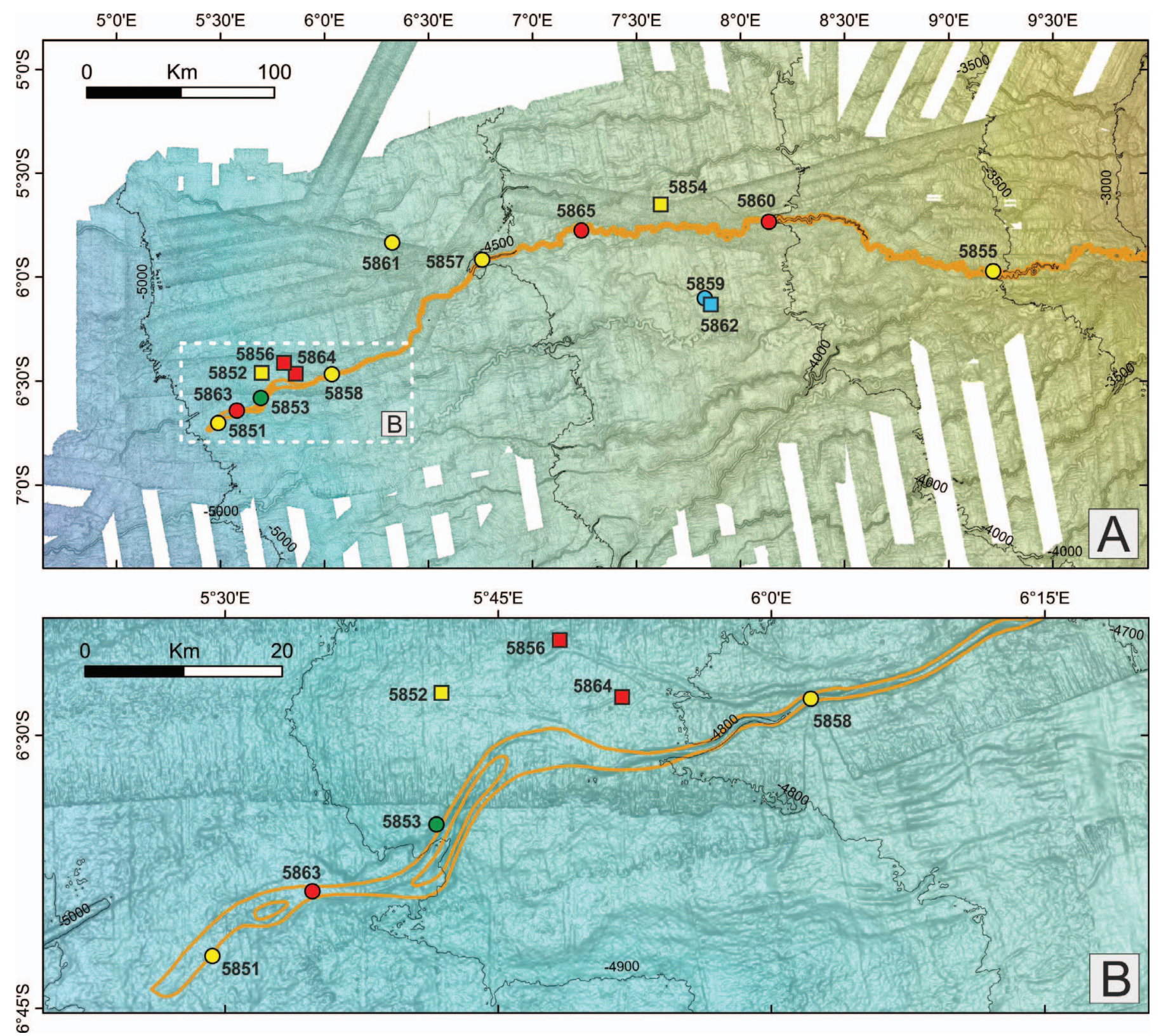

Fig. 2.-Location of the studied channel (circles) and lobe (squares) samples cored in the Congo Fan. The white dashed rectangle in Part A outlines the area enlarged in Part B. Scientific cruises: red, ZAIANGO1 (Savoye 1998); yellow, ZAIANGOROV (Savoye and Ondréas 2000); blue, REPREZAI_LEG1 (Marsset and Droz 2010); green, CONGOLOBE (Rabouille 2011).

\section{COMPOSITIONAL SIGNATURES OF CONGO FAN TURBIDITES}

The studied Congo Fan sediments (Table 2) are mostly fine-grained, moderately to poorly sorted, positively skewed, and leptokurtic sands (textural parameters calculated by laser granulometry after Folk 1980). Grain size ranges from silt up to fine sand for abandoned lobe $(5.1 \phi$ and $2.9 \phi)$ and abandoned channel facies (3.2 $\phi$ and $2.4 \phi)$ and from fine up to lower coarse sand for active lobe (from $2.9 \phi$ to $1.7 \phi$ ) and active channel facies (from $2.9 \phi$ to $0.9 \phi$ ). All samples contain a fraction of coarse sand and most samples a fraction of very coarse sand (1-2 mm) or even granules (2-4 mm), which represent $8 \%$ of the coarsest sample (5865). In all samples, the coarsest grains are invariably monocrystalline quartz (Fig. $3 \mathrm{~A}-\mathrm{D}$ ), whereas the coarsest feldspar grains reach at most $0.8 \mathrm{~mm}$ and are invariably K-feldspar (generally cross-hatched microcline, or locally perthite as in Fig. 3E). No correlation was observed between grain size and water depth or distance from shore. Even at water depths between 4000 and $5000 \mathrm{~m}$ b.s.l., the size of quartz grains is not smaller than in river sand, indicating the lack of a significant fining trend during $>1000 \mathrm{~km}$ of turbiditic transport from the land to the deep sea.

In the description of compositional variability, a clear distinction is made between differences observed among samples (intersample variability) and among grain-size classes of the same sample (intrasample variability; Garzanti et al. 2009).

\section{Petrography and Heavy Minerals}

Sand samples range from quartzose to pure quartzose, with dominant monocrystalline quartz commonly showing a rounded outline or abraded 
TABLE 2.-Key grain-size, mineralogical, and geochemical parameters characterizing the 15 studied sediment samples (ordered from finest to coarsest).

GSZ (grain size in phi units, as determined by wet sieving); Q, quartz (Qp, polycrystalline); F, feldspars (KF, K-feldspar; $P$, plagioclase; Mic, microcline, Mic*, cross-hatched KF); L, lithic grains; tHMC, transparent heavy-mineral concentration; ZTR, zircon + tourmaline + rutile; Ep, epidote; Grt, garnet; St, staurolite; Ky, kyanite; Sil, sillimanite; Amp, amphibole; \&tHM, other transparent heavy minerals (mainly, titanite, apatite, allanite, andalusite. and monazite). Model ages in Ma.

\begin{tabular}{|c|c|c|c|c|c|c|c|c|c|c|c|c|c|c|c|c|c|c|c|c|c|c|c|c|c|c|c|c|}
\hline Sample & GSZ & Q & $\mathrm{F}$ & $\mathrm{L}$ & $\begin{array}{l}\mathrm{Qp} / \\
\mathrm{Q} \%\end{array}$ & $\begin{array}{c}\mathrm{P} / \\
\mathrm{F} \%\end{array}$ & $\begin{array}{c}\mathrm{Mic} / \\
\mathrm{F} \%\end{array}$ & tHMC & ZTR & Ep & Grt & St & Ky & Sil & Amp & \&tHM & $\mathrm{Ba}$ & $\mathrm{Y}$ & LREE & HREE & $\mathrm{Zr}$ & $\mathrm{Hf}$ & $\begin{array}{l}\mathrm{La}_{\mathrm{N}} / \\
\mathrm{Yb}_{\mathrm{N}}\end{array}$ & $\begin{array}{l}\mathrm{Ce} / \\
\mathrm{Ce} *\end{array}$ & $\begin{array}{l}\mathrm{Eu} / \\
\mathrm{Eu}^{*}\end{array}$ & $\epsilon \mathrm{Nd}$ & $\mathrm{T}_{\mathrm{Nd}, \mathrm{CHUR}}$ & $\mathrm{T}_{\mathrm{Nd}, \mathrm{DM}}$ \\
\hline 5854 & 5.27 & 89 & 10 & 1 & n.d. & 33 & 47 & 0.3 & 40 & 34 & 1 & 3 & 2 & 5 & 12 & 1 & 197 & 7.4 & 39 & 5.1 & 323 & 8.2 & 6.5 & 0.98 & 0.61 & -14.79 & 1430 & 1974 \\
\hline 5859 & 3.32 & 90 & 9 & 2 & n.d. & 31 & 43 & 0.4 & 36 & 35 & 4 & 3 & 4 & 2 & 13 & 2 & 133 & 2.7 & 13 & 1.9 & 176 & 3.3 & 5.9 & 0.92 & 0.63 & -15.88 & 1547 & 2073 \\
\hline 5863 & 2.91 & 91 & 8 & 1 & 4 & 23 & $14^{*}$ & 0.4 & 47 & 37 & 2 & 1 & 1 & 1 & 9 & 0.5 & 127 & 3.0 & 16 & 2.4 & 238 & 5.3 & 6.0 & 0.77 & 0.66 & -15.87 & 1673 & 2209 \\
\hline 5862 & 2.88 & 94 & 5 & 1 & 3 & 39 & $13 *$ & 0.4 & 43 & 28 & 4 & 7 & 1 & 1 & 15 & 0.5 & 91 & 3.4 & 25 & 2.6 & 353 & 8.2 & 7.5 & 0.94 & 0.43 & -16.32 & 1501 & 2011 \\
\hline 5856 & 2.83 & 97 & 2 & 1 & 4 & 11 & $11^{*}$ & 0.3 & 55 & 29 & 1 & 4 & 1 & 0.5 & 7 & 2 & 98 & 2.6 & 8 & 1.9 & 305 & 6.7 & 3.3 & 0.87 & 0.84 & -15.38 & 1622 & 2167 \\
\hline 5858 & 2.61 & 95 & 4 & 2 & 3 & 21 & $7^{*}$ & 0.3 & 51 & 33 & 3 & 4 & 3 & 1 & 5 & 0 & 96 & 3.7 & 27 & 3.0 & 377 & 7.1 & 7.9 & 0.92 & 0.48 & -16.39 & 1421 & 1919 \\
\hline 5851 & 2.45 & 96 & 3 & 0 & 3 & 50 & $25^{*}$ & 0.3 & 52 & 29 & 2 & 4 & 3 & 2 & 6 & 1 & 100 & 2.8 & 11 & 2.0 & 277 & 6.2 & 4.7 & 0.89 & 0.73 & -18.72 & 1877 & 2354 \\
\hline 5861 & 2.41 & 95 & 5 & 0 & 2 & 42 & $11 *$ & 0.3 & 35 & 35 & 7 & 5 & 2 & 2 & 14 & 1 & 85 & 1.8 & 6 & 1.2 & 156 & 2.9 & 4.0 & 0.84 & 0.73 & -15.89 & 1556 & 2082 \\
\hline 5857 & 2.37 & 95 & 4 & 1 & 3 & 29 & $6^{*}$ & 0.3 & 49 & 28 & 3 & 6 & 2 & 1 & 8 & 2 & 86 & 5.0 & 8 & 2.8 & 97 & 2.1 & 2.2 & 0.86 & 0.50 & -17.99 & 2834 & 3257 \\
\hline 5855 & 2.24 & 97 & 2 & 1 & 2 & 22 & $22 *$ & 0.2 & 60 & 20 & 4 & 2 & 3 & 1 & 5 & 2 & 56 & 1.7 & 8 & 1.2 & 89 & 1.9 & 5.0 & 0.91 & 0.64 & -18.86 & 1765 & 2235 \\
\hline 5864 & 1.67 & 96 & 3 & 1 & 5 & 15 & $9^{*}$ & 0.3 & 50 & 20 & 0.5 & 7 & 12 & 0.5 & 12 & 0 & 63 & 2.0 & 8 & 1.5 & 224 & 4.9 & 4.3 & 0.81 & 0.70 & -18.66 & 2087 & 2564 \\
\hline
\end{tabular}

overgrowths. K-feldspar prevails over plagioclase. The few lithic fragments include durable felsitic volcanic, quartzose siltstone-metasiltstone, and chert grains. Mica (muscovite $\geq$ biotite) occurs in all samples but represents $\leq 2 \%$ of total detritus. Calcite grains are rare. A few yellowish green glaucony grains (Fig. 3A), clay chips, and locally large laterite fragments (Fig. 3F) or bioclasts (forams) are found in several samples.

The very poor tHM suite of Congo Fan sediments include epidote, zircon, tourmaline, amphibole, rutile, minor staurolite, garnet, kyanite, prismatic or fibrolitic sillimanite, and rare titanite, apatite, augitic clinopyroxene, allanite, andalusite, and monazite. Most detrital minerals are angular to subangular and apparently unweathered. Only amphiboles or the rare pyroxene grains sporadically display deep etching along cleavage planes. Corrosion is visible on most titanite and epidote grains, and on a third of garnet, staurolite, and kyanite grains. Among the most durable minerals, $\sim 45 \%$ of zircon grains, $\sim 30 \%$ of rutile grains, and only $\sim 5 \%$ of tourmaline grains appear corroded. Only zircon is frequently subrounded $(15 \%)$ or even well rounded $(4 \%)$, and only apatite and monazite are frequently subrounded (50\% and $30 \%$, respectively). A few opaque Fe-Ti-Cr oxides and exceptionally epidote are subrounded to well rounded.

\section{Intersample Mineralogical Variability}

Intersample compositional variability is limited (Fig. 4). Quartz tends to increase with grain size at the expense of all other detrital components. Carbonates (mostly calcite) occur only in finer samples (silt to lower fine sand). Mica is common in both finest and coarsest samples. The silt sample has slightly less zircon, garnet, opaque Fe-Ti-Cr oxides, and slightly more sillimanite and tourmaline than most sand samples. Overall, less dense heavy minerals (sillimanite, amphibole) tend to be concentrated in finer samples and densest minerals (kyanite, zircon, Fe-Ti-Cr oxides) in coarser samples, but correlation of mineralogical parameters with grain size is poor (significance level $5-10 \%$ at most).

\section{Intrasample Mineralogical Variability}

Raman counting of five distinct size classes for each of the three finestgrained samples $(5853,5854$, and 5859) allowed us to outline a clear mineralogical trend. Whereas quartz is dominant in the coarse tail of the size distribution, feldspars and especially plagioclase are concentrated in the fine tail. The $\mathrm{Q} / \mathrm{F}$ ratio thus increases from $2.3-3.4$ in the $5-32 \mathrm{~mm}$ class, to $4.3-4.8$ in the $32-63 \mathrm{~mm}$ class, to $8.2-9.5$ in the $63-125 \mathrm{~mm}$ class, to $13-28$ in the $125-250 \mathrm{~mm}$ class, and up to $>33$ in the $250-500$ $\mathrm{mm}$ class. The $\mathrm{Mic} / \mathrm{F}$ ratio increases from $27-33 \%$ in silt classes, to $45-$ $50 \%$ in the $63-125 \mathrm{~mm}$ class, to $43-100 \%$ in the $125-250 \mathrm{~mm}$ class, and up to $83-100 \%$ in the $250-500 \mathrm{~mm}$ class. The $\mathrm{P} / \mathrm{F}$ ratio, instead, decreases from $49-67 \%$ in silt classes, to $35-41 \%$ in the $63-125$ mm class, to $0-36 \%$ in the $125-250 \mathrm{~mm}$ class, and down to $0 \%$ in the $250-500 \mathrm{~mm}$ class. Carbonates occur in silt $(0.5-1.6 \%$ and up to $3.1 \%$ of total grains in the 5$32 \mathrm{~mm}$ class) but only very sporadically in sand. Mica occurs in all classes, reaching maximum invariably in the $63-125 \mathrm{~mm}$ class $(3.0-3.7 \%$ of total grains).

\section{Trace Elements}

Because of strong quartz dilution in Congo Fan sediments, trace elements are markedly depleted relative to the Upper Continental Crust standard (UCC; Taylor and McLennan 1995; Rudnick and Gao 2003) (Table 2). The degree of depletion increases with grain size and most steadily for $\mathrm{Ba}(r=-0.75)$. Only $\mathrm{Zr}$ and $\mathrm{Hf}$ are undepleted, having concentrations of $264 \pm 86 \mathrm{ppm}$ and $5.8 \pm 1.8 \mathrm{ppm}$ in silt to lower fine sand, and of $136 \pm 56 \mathrm{ppm}$ and $2.8 \pm 1.2 \mathrm{ppm}$ in coarser samples. The concentration of $Y$ and total REE reaches maximum in silt and is relatively high in the two lower-fine sands 5858 and 5862 also characterized by the highest concentration in $\mathrm{Zr}$ and $\mathrm{Hf}$. Coarser-grained sand has the lowest concentration in $\mathrm{Zr}$, Hf, and total REE.

REE patterns normalized to CI carbonaceous chondrites (Barrat et al. 2012) display classical LREE enrichment and negative Eu anomaly (Table 2; McLennan et al. 1990, 1993), but with notable variability (Fig. 5). Silt and lowermost fine-grained sand $(\geq 2.9 \phi)$ display steeper patterns than upper fine to lower coarse sand $\left(\mathrm{La}_{\mathrm{N}} / \mathrm{Yb}_{\mathrm{N}} 5.9-6.5\right.$ vs. mostly 3.8-5.0). Patterns are steepest for samples 5858 and $5862\left(\mathrm{La}_{\mathrm{N}} / \mathrm{Yb}_{\mathrm{N}} 7.9\right.$ and 7.5), which also show the most negative Eu anomaly ( $\mathrm{Eu} / \mathrm{Eu}^{*} 0.48$ and 0.43$)$, and least steep for sample $5857\left(\mathrm{La}_{\mathrm{N}} / \mathrm{Yb}_{\mathrm{N}} 2.2 ; \mathrm{Eu} / \mathrm{Eu}^{*} 0.50\right)$. The $\mathrm{Eu}$ anomaly is least negative for samples 5852 and $5856\left(\mathrm{Eu} / \mathrm{Eu}^{*} 0.81\right.$ and 0.84 ) and is otherwise $0.65 \pm 0.06$. All samples show negative $\mathrm{Ce}$ anomaly ( $\mathrm{Ce} / \mathrm{Ce}^{*}$ as low as 0.77 for 5863$)$ and an otherwise convexupward and moderately steep LREE pattern $\left(\mathrm{La}_{\mathrm{N}} / \mathrm{Sm}_{\mathrm{N}} 3.4-4.2\right.$, excepting 


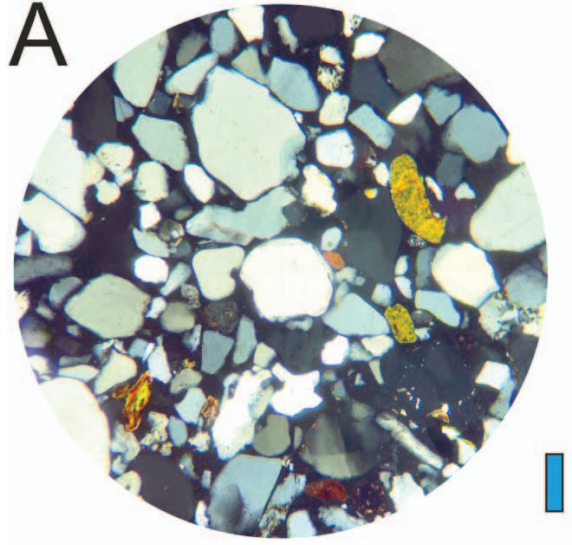

5860 active channel

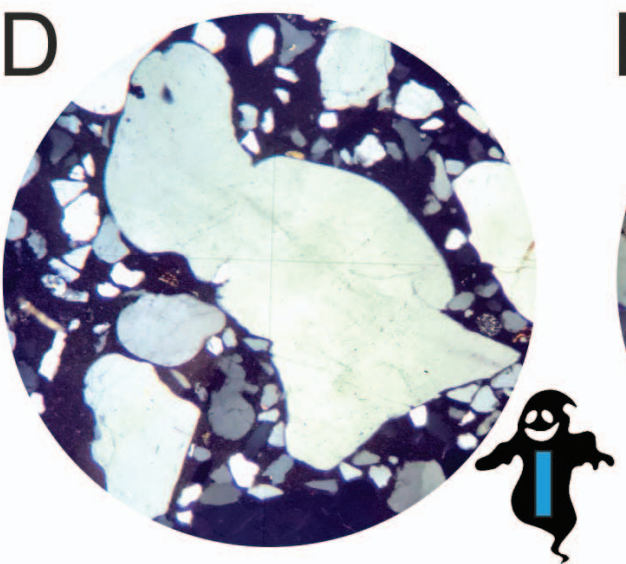

5865 active channel

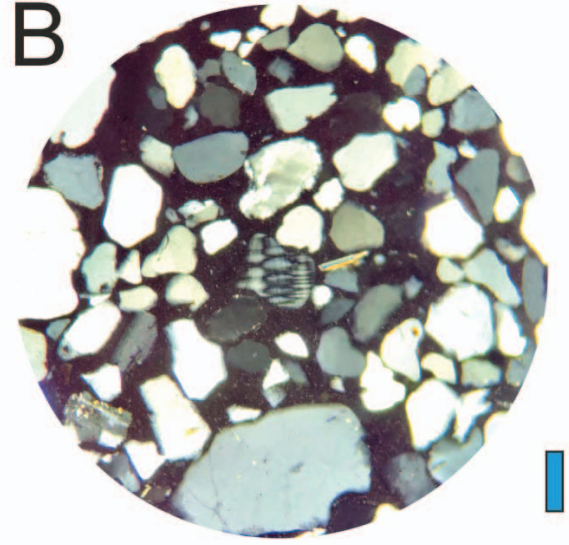

5861 abandoned channel

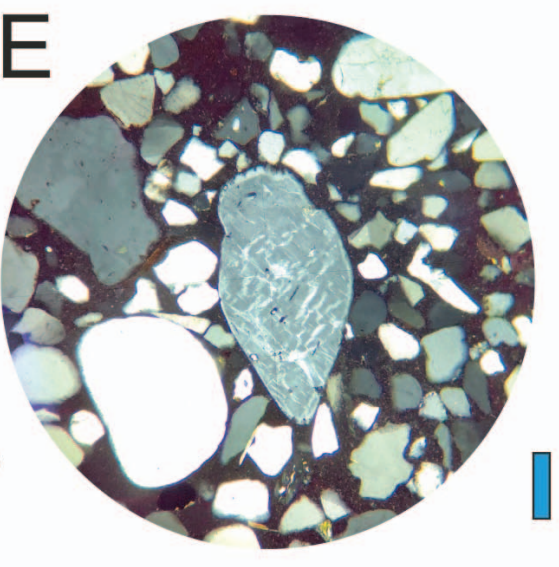

5865 active channel

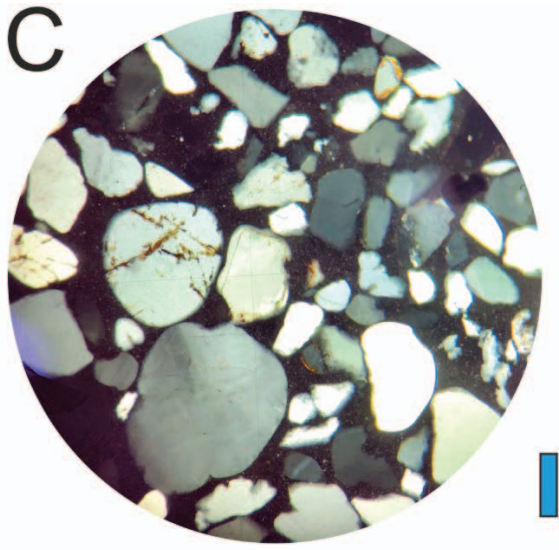

5864 active lobe

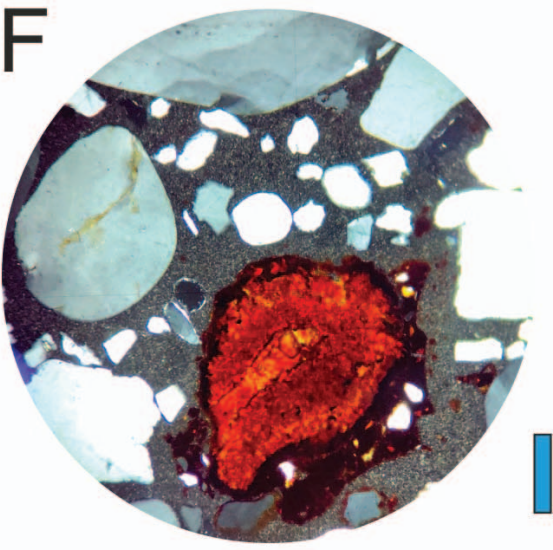

5865 active channel

FIg. 3.-Petrography of fine to coarse Congo Fan sands (blue vertical scale bar $200 \mathrm{~mm}$ ). A) Pure quartzose sand with monocrystalline quartz displaying abraded overgrowths (center) and yellowish glaucony grains (right). B) Quartzose sand with cross-hatched microcline (center). C) Pure quartzose sand with monocrystalline quartz showing rounded outline and infillings of iron-stained brownish clay along lattice discontinuities (left) or reworked overgrowths (adjacent grain to the right). D) "Ghostshaped" largest quartz grain in all samples. E) Largest alkali-feldspar in all samples (center) associated with unstrained monocrystalline quartz with subrounded outline. F) Laterite clast and subrounded monocrystalline quartz reaching granule size (top).

sample 5858, where $\mathrm{La}_{\mathrm{N}} / \mathrm{Sm}_{\mathrm{N}}$ is 5.0$)$. $\mathrm{Gd}_{\mathrm{N}} / \mathrm{Ho}_{\mathrm{N}}$ is $1.2-1.4$ in silt to lowermost fine sand and mostly $1.0-1.1$ in coarser sand, whereas $\mathrm{Ho}_{\mathrm{N}} / \mathrm{Yb}_{\mathrm{N}}$ is between 0.65 and 0.8 . The HREE pattern is thus concave upward for all samples excepting 5857, where $\mathrm{Gd}_{\mathrm{N}} / \mathrm{Ho}_{\mathrm{N}}$ is 0.7 (Fig. 5).

\section{Nd Isotopes and Model Ages}

The $\varepsilon_{\mathrm{Nd}}$ values of the 15 studied samples range from -14.8 for silt sample 5854 to -21.2 for coarse-sand sample 5865 , being $-17 \pm 2$ on average for the nine fine-sand samples (Fig. 6). Grain-size control on $\varepsilon_{\mathrm{Nd}}$ values is indicated by highly significant correlation ( $r=$ between -0.81 and -0.86 depending on the method of grain-size measurement; the probability that a correlation coefficient $>0.76$ is obtained by chance with 15 data points is $<0.1 \%$ ).

In the studied Congo Fan sediments, Nd model ages calculated relative to CHUR are mostly early Mesoproterozoic to late Paleoproterozoic ( $\mathrm{T}_{\mathrm{Nd}, \mathrm{CHUR}}$ from 1421 to $1877 \mathrm{Ma}$; Calymmian to late Orosirian), whereas depleted mantle model ages are mostly Paleoproterozoic $\left(\mathrm{T}_{\mathrm{Nd}, \mathrm{DM}}\right.$ from 1919 and $2354 \mathrm{Ma}$; mid Orosirian to late Siderian). Exceptions include the two coarsest-grained samples 5864 and 5865, which yielded Rhyacian $\left(\mathrm{T}_{\mathrm{Nd}, \mathrm{CHUR}} 2087\right.$ and $\left.2288 \mathrm{Ma}\right)$ and Neoarchean model ages $\left(\mathrm{T}_{\mathrm{Nd}, \mathrm{DM}} 2564\right.$ and $2712 \mathrm{Ma}$ ), and especially sample 5857, which yielded much older,
Mesoarchean and Paleoarchean model ages $\left(\mathrm{T}_{\mathrm{Nd}, \mathrm{CHUR}} 2834 \mathrm{Ma} ; \mathrm{T}_{\mathrm{Nd}, \mathrm{DM}}\right.$ $3257 \mathrm{Ma}$ ). The difference between $\mathrm{T}_{\mathrm{Nd}, \mathrm{DM}}$ and $\mathrm{T}_{\mathrm{Nd}, \mathrm{CHUR}}$ model ages is on average $\sim 500 \mathrm{Ma}$, and tends to decrease with grain size from $544 \mathrm{Ma}$ for the finest sample 5854 to $424 \mathrm{Ma}$ for the coarsest sample $5865(r=-0.72)$.

\section{THE VARIABILITY OF COMPOSITIONAL SIGNALS}

In this section we shall focus on the causes of compositional variability, paying specific attention to the grain-size dependence of mineralogical and geochemical parameters and discussing chemical weathering, hydraulic sorting, recycling, and sediment mixing as other potential controlling factors.

\section{Intrasample Mineralogical Variability}

The systematic concentration of quartz in coarser classes and of feldspars in finer classes of the studied samples cannot be accounted for by settling equivalence, because quartz and feldspars do not have markedly dissimilar density and shape (Garzanti et al. 2008). An increase in the $Q / F$ ratio with increasing grain size has long been documented from sandstone suites deposited in diverse continental to shallow-marine environments (e.g., Graham 1930; Odom et al. 1976) but less frequently from deep-sea 


\section{INTERSAMPLE MINERALOGICAL VARIABILITY}

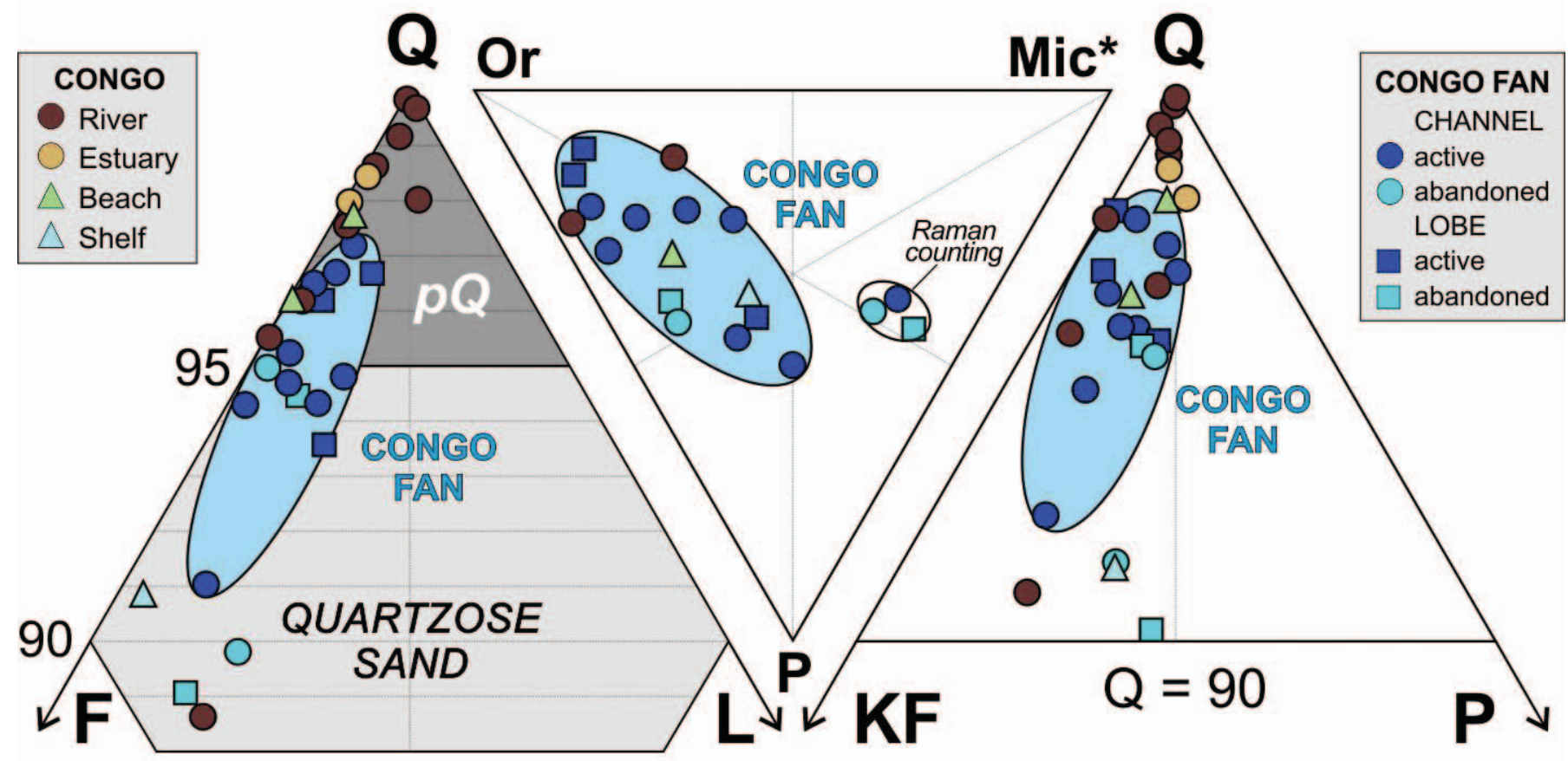

INTRASAMPLE MINERALOGICAL VARIABILITY

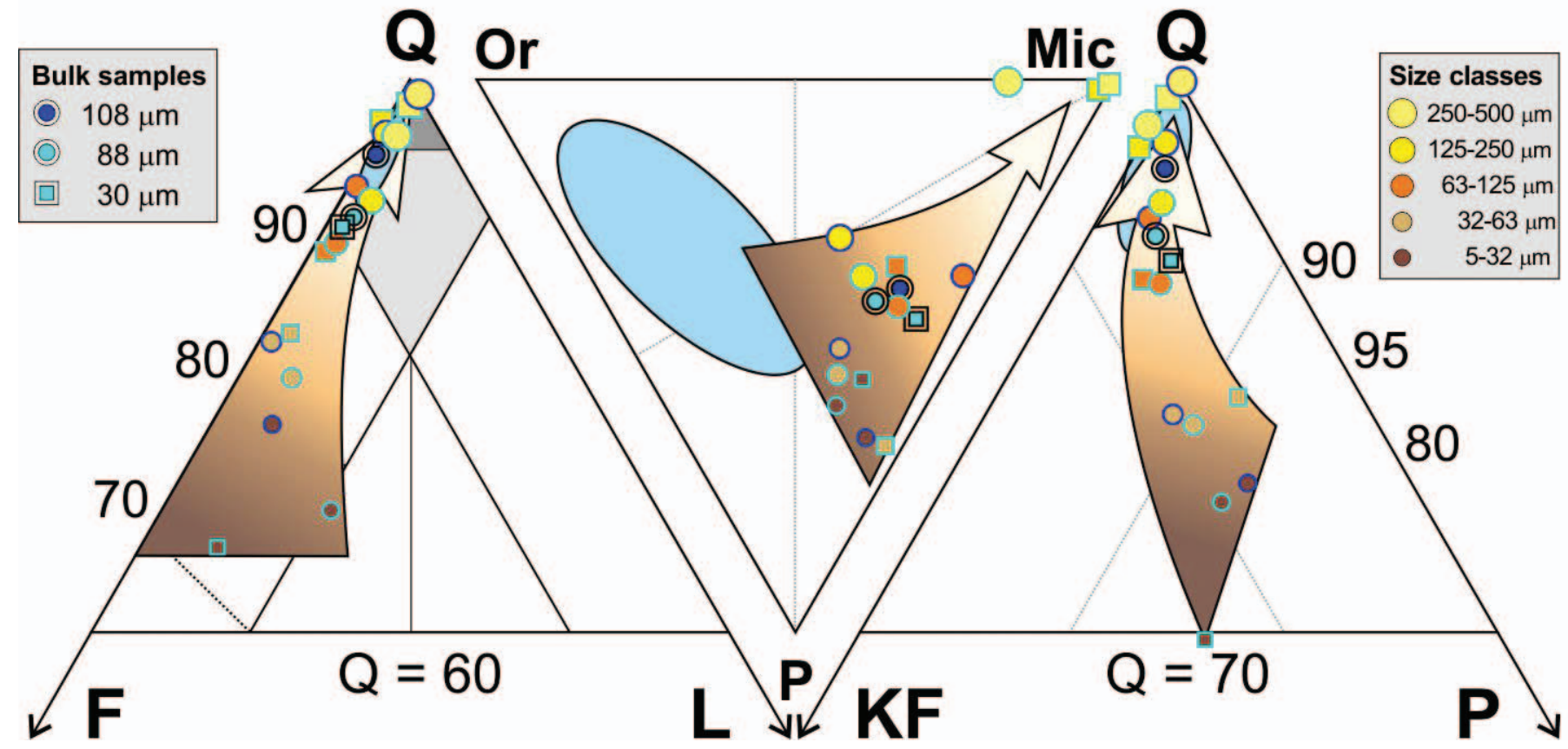

FIG. 4.-Detrital modes in the Congo source-to-sink system (data for river, estuary, beach, and shelf sands after Garzanti et al. 2019a). Above) Limited intersample variability of turbidite sands ( $p Q$, pure quartzose field). Below) Strong intrasample variability assessed by Raman counting of five distinct classes in each of the three finestgrained samples, which allows identification of untwinned microcline. In the fine tail of the size distribution, plagioclase is concentrated relative to K-feldspar, orthoclase relative to microcline, and microcline relative to quartz. Q, quartz; F, feldspars (KF, K-feldspar; Or, untwinned KF; Mic, microcline, Mic*, cross-hatched KF; P, plagioclase); $\mathrm{L}$, lithic fragments. 


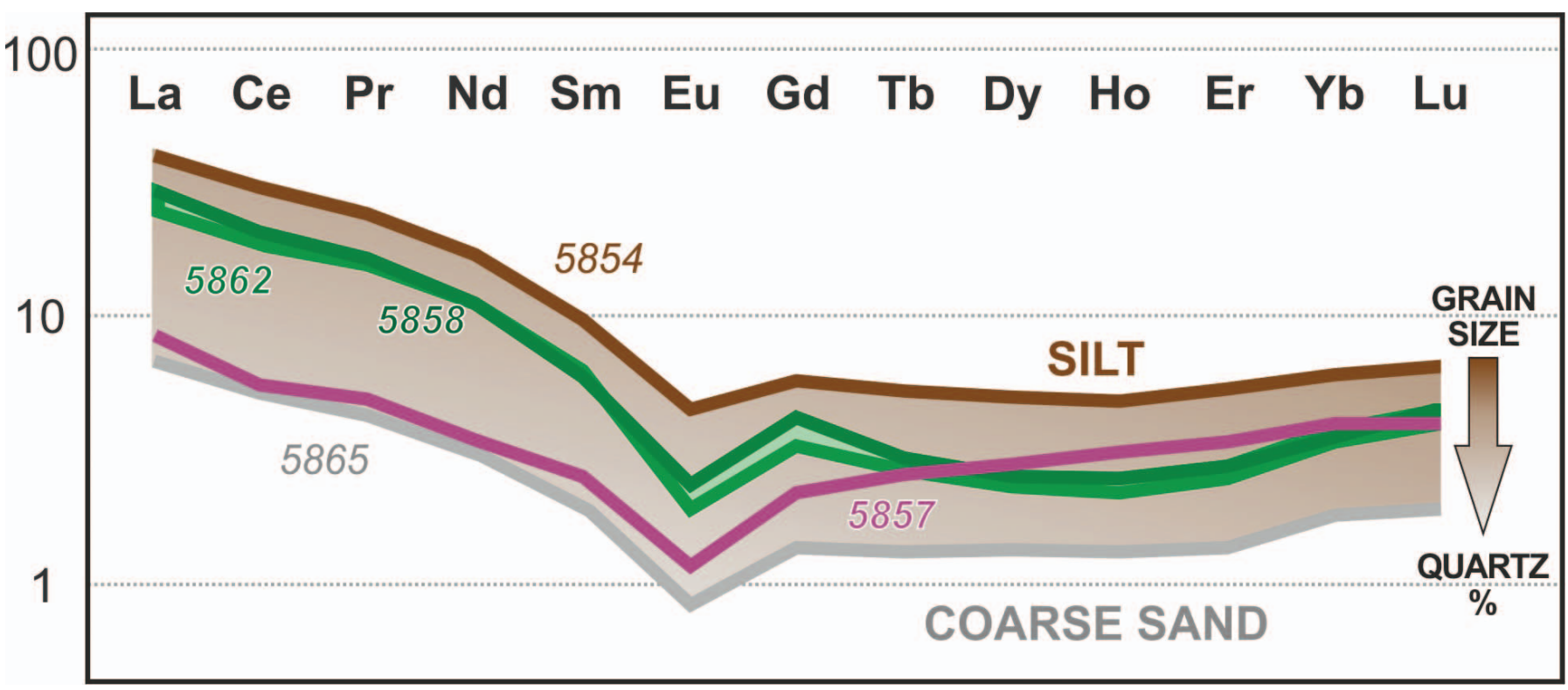

FIG. 5.-Variability of REE patterns in Congo Fan sediments (normalization to CI carbonaceous chondrite values after Barrat et al. 2012). REE content decreases with increasing grain size and quartz content from silt (5854) to coarse sand (5865). Sand samples 5858 and 5862 enriched in LREE-rich minerals (monazite and/or allanite) have the steepest patterns. All samples have a concave-upward HREE pattern, but not sample 5857, where the presence of a rare yttrium-rich mineral is indicated.

turbidites (e.g., Marsaglia et al. 1996). The concentration of feldspar grains in finer size classes was generally ascribed to selective mechanical comminution (e.g., Dutta et al. 1993), explained by the good cleavability coupled with greater susceptibility to weathering especially of detrital plagioclase (Basu 1976; Garzanti 1986). Studies of modern sand, however, have demonstrated that mechanical abrasion in high-energy glacial, fluvial, eolian, or coastal environments is able to modify the Q/F ratio only slightly (Russell 1937; Pollack 1961; Breyer and Bart 1978; Nesbitt and Young 1996; Garzanti et al. 2015b) and that the grain-size distribution of detrital feldspars may be influenced by other factors, including their original size distribution in source rocks, recycling, and sediment mixing (Hayes 1962; McBride et al. 1996; Dott 2003).
In three transects across the Atlantic passive margin of southern Africa, from northern Namibia to the Congo mouth, the relative abundance of feldspar is invariably seen to increase from coarser-grained coastal sand to finer-grained offshore sand, silt, and silty clay. The $\mathrm{Q} / \mathrm{F}$ ratio decreases from $3.2 \pm 0.7$ in eolian-dune, beach, and shelf sediments of northern Namibia and southern Angola to 1.3 on the Walvis Ridge offshore, from $1.7 \pm 0.8$ in river sands of central Angola to $0.8-1.1$ offshore, and from 64 \pm 3 in the Soyo estuary to $\sim 10$ on the shelf offshore (Garzanti et al. 2018a). Although locally caused by mixing with longshore-drifting sand richer in feldspars (e.g., offshore of the Congo mouth), such intersample variability suggests that feldspar grains tend to be significantly smaller than quartz grains. Instead, no marked differences in the $\mathrm{P} / \mathrm{F}$ ratio were

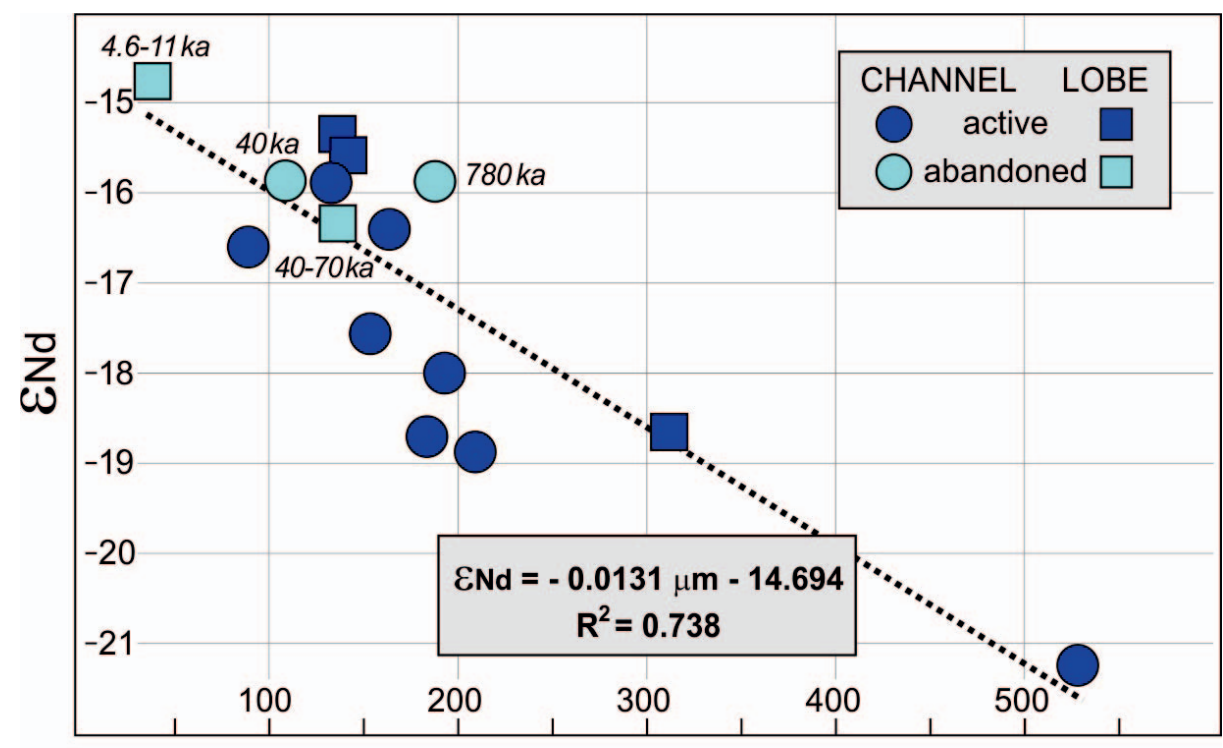

GRAIN SIZE $(\mu \mathrm{m})$
FIG. 6.-Grain-size-dependent intersample variability of $\varepsilon_{\mathrm{Nd}}$ values, which become markedly more negative with increasing sample grain size. Samples from active channels tend not only to be slightly coarser-grained but also to have more negative $\varepsilon_{\mathrm{Nd}}$ values than lobe and older channel samples relative to what expected for their grain size. Ages of abandoned lobe and channel samples as in Table 1 . 
detected between coastal sands and finer-grained offshore sediments in northern Namibia to southern Angola $(65 \pm 8 \%$ vs. $\sim 72 \%$ ) or central Angola ( $42 \pm 5 \%$ vs. $44 \pm 5 \%$ ). Because chemical weathering can be considered negligible in the hyperarid coast of Namibia and southern Angola, and in semiarid central Angola as well (Dinis et al. 2017), the size reduction of feldspar grains in these regions appears to be fundamentally caused by mechanical comminution. Especially in eolian environments, where the effects of grain-to-grain impacts are much more effective than in water, feldspars are prone to break along cleavage or twin planes while hit by harder minerals that lack cleavage such as quartz or garnet (Resentini et al. 2018). The more marked compositional trends observed in Congo Fan sediments, however, call for a more complex explanation.

\section{Mechanical vs. Chemical Durabilities of Detrital Silicates}

As a first approximation, mechanical durability can be considered to be roughly proportional to mineral hardness, traditionally defined as the resistance which a smooth surface offers to scratching (abrasion) and classically evaluated empirically by the relative Mohs scale. Resistance to scratching, however, involves components of loading and shearing and is different from resistance to indentation, which is measured as the response to loading by units of pressure (e.g., GPa; Whitney et al. 2007). Although it could represent a better "absolute" numerical indicator of resistance to mechanical breakdown, indentation hardness is quantitatively assessed using different indenter shapes and experimental techniques (e.g., depthsensing indentation, indentation-induced cracking) and it is thus defined in different ways (e.g., microhardness, DSI hardness, DSI elastic modulus, fracture toughness; Broz et al. 2006). In Mohs' scale, orthoclase defines grade 6 and quartz grade 7, with plagioclase and microcline ranging between 6 and 6.5. In absolute terms, quartz results to be tougher than orthoclase by factors between 1.3 and 1.8 according to all methods (Whitney et al. 2007).

The chemical durability of rock-forming minerals at the conditions met at the Earth's surface, instead, is classically considered to follow in reverse the order of crystallization from high-temperature melts indicated by the Bowen series (Goldich 1938). During active leaching, the removal rate of $\mathrm{Na}^{+}$and $\mathrm{Ca}^{2+}$ from plagioclase exceeds the removal rate of $\mathrm{K}^{+}$from $\mathrm{K}$ feldspar under most circumstances, and the most durable among Kfeldspars results to be the low-temperature ordered polymorph microcline. The ability of detrital tectosilicates to survive weathering has thus long been assumed to follow the order plagioclase $<$ orthoclase $<$ microcline $<$ quartz (Blatt 1967; Nesbitt et al. 1997).

In Congo Fan sediments, the grain-size-dependent variability of the $\mathrm{Q} / \mathrm{F}$ ratio is greater than along the coast to the south, and the $\mathrm{P} / \mathrm{F}$ ratio is observed to increase and the Mic/F ratio to decrease significantly from coarser to finer sand classes and most markedly in silt classes (Fig. 4). Because the differences in purely mechanical durability are only moderate among detrital feldspars, the systematic increase in plagioclase relative to $\mathrm{K}$-feldspar, of orthoclase relative to microcline, and of K-feldspar relative to quartz with decreasing grain size cannot be ascribed entirely to their different resistance to mechanical comminution during fluvial or turbiditic transport. Their different resistance to intense chemical weathering in hothumid equatorial climate, in the present sedimentary cycle and possibly in previous ones as well, must have played a major role.

Strong weathering also explains why carbonate grains occur in silt but not in sand (as observed in Brahmaputra sediments; Singh and FranceLanord 2002). Neoproterozoic carbonate rocks are extensively exposed along the Atlantic Rise, but carbonate detritus is effectively dissolved because of high $p \mathrm{CO}_{2}$ levels in soils or river waters, and only sporadic siltsize calcite and dolomite grains are found in fluvial and turbiditic sediments.

Careful textural analysis failed to provide additional cogent information on weathering intensity (Appendix Table A5). In Congo Fan turbidites, as in Congo River sand, commonly rounded to well-rounded quartz grains occasionally show deep corrosion or incipient replacement by iron-stained clay along microfractures and other lattice discontinuities (Fig. 3C), but less commonly and extensively than observed in northern Angola (compare with Figure 7 in Garzanti et al. 2018a). Laterite fragments occur (Fig. 3F) but, despite the hot hyper-humid climate characterizing most of the Congo catchment, corrosion features on detrital minerals are notably less widespread than in equatorial highlands of the East African rift (Garzanti et al. 2013a). Such discrepancies might be ascribed to extensive recycling and limited durability of deeply etched grains.

In most samples, the coarsest heavy minerals are typically kyanite, staurolite, or garnet, which may reflect their originally coarser size in metapelitic source rocks and partly the greater mechanical durability of staurolite and garnet (as observed in eolian sand of Nambian ergs; Resentini et al. 2018). Despite their lower density — which would imply a larger size according to the settling-equivalence principle (Rubey 1933) tourmaline and hornblende are rarely equally coarse-grained, which may be ascribed, respectively, to generally smaller size in source rocks and to reduced mechanical durability owing to good cleavability.

\section{Intersample Mineralogical Variability}

The mineralogy of Congo Fan sand is quite homogeneous (Fig. 4). Quartz enrichment not only in the coarser classes of each sample but also in coarser samples, and feldspar enrichment not only in the finest classes of each sample but also in silt, is explained by their different mechanical and chemical durabilities, as discussed above. Transparent-heavy-mineral concentration is invariably very poor and virtually unchanged from silt to coarse sand, and tHM suites show only a weak association of denser minerals with sand and of epidote and less dense minerals with finer grain sizes (Fig. 7), a tendency much more evident in the Indus Fan and in the Bengal sedimentary system (Andò et al. 2019; Borromeo et al. 2019; Garzanti et al. 2019b, 2020). Selective-entrainment effects, best revealed by geochemical data as discussed below, are limited in the Congo Fan, pointing to minimum reworking by bottom currents at the abyssal depths of Atlantic Ocean floors.

\section{Intersample Geochemical Variability}

Although heavy-mineral concentration is constantly very poor in all studied samples (tHMC $0.33 \pm 0.06$ ), geochemical data reveal a significant intersample compositional variability controlled by both grain size and very slight local hydrodynamic enrichment in densest minerals. All analyzed trace elements (Ba, Y, REE, Zr, and $\mathrm{Hf}$ ) tend to be more abundant, and REE patterns steeper, in finer-grained samples, reaching the highest values in silt and the lowest values in medium to coarse sand. Such grain-size-dependent variability chiefly reflects the increase of quartz, which is quite poor in trace elements, with increasing grain size. Conversely, the negative correlation between grain size and $\mathrm{Ba}$, which is hosted mostly in K-feldspar, chiefly reflects the concentration of feldspar in finer samples.

It is noteworthy that many studied samples are enriched in $\mathrm{Zr}$ and $\mathrm{Hf}$ relatively to the UCC standard, with the highest values reached in silt and in lower-fine sands 5858 and 5862. Samples 5858 and 5862 also show a relatively high content in $\mathrm{Y}$ and REE, together with the steepest REE patterns and most negative $\mathrm{Eu}$ anomalies, testifying to slightly greater concentration of zircon, monazite, and/or allanite than in other sand samples. Conversely, the concentrations of $\mathrm{Zr}$, Hf, Y, and REE are lowest in fine sand 5860, hinting at hydrodynamic depletion in densest minerals. Lower-fine sands 5852 and 5856 contain relatively low LREE and display less steep REE pattern and the least negative Eu anomaly, features ascribed to low contents of monazite. Sample 5857 is even poorer in LREE, displays the least steep REE pattern, and is the richest sand in $\mathrm{Y}$ and 


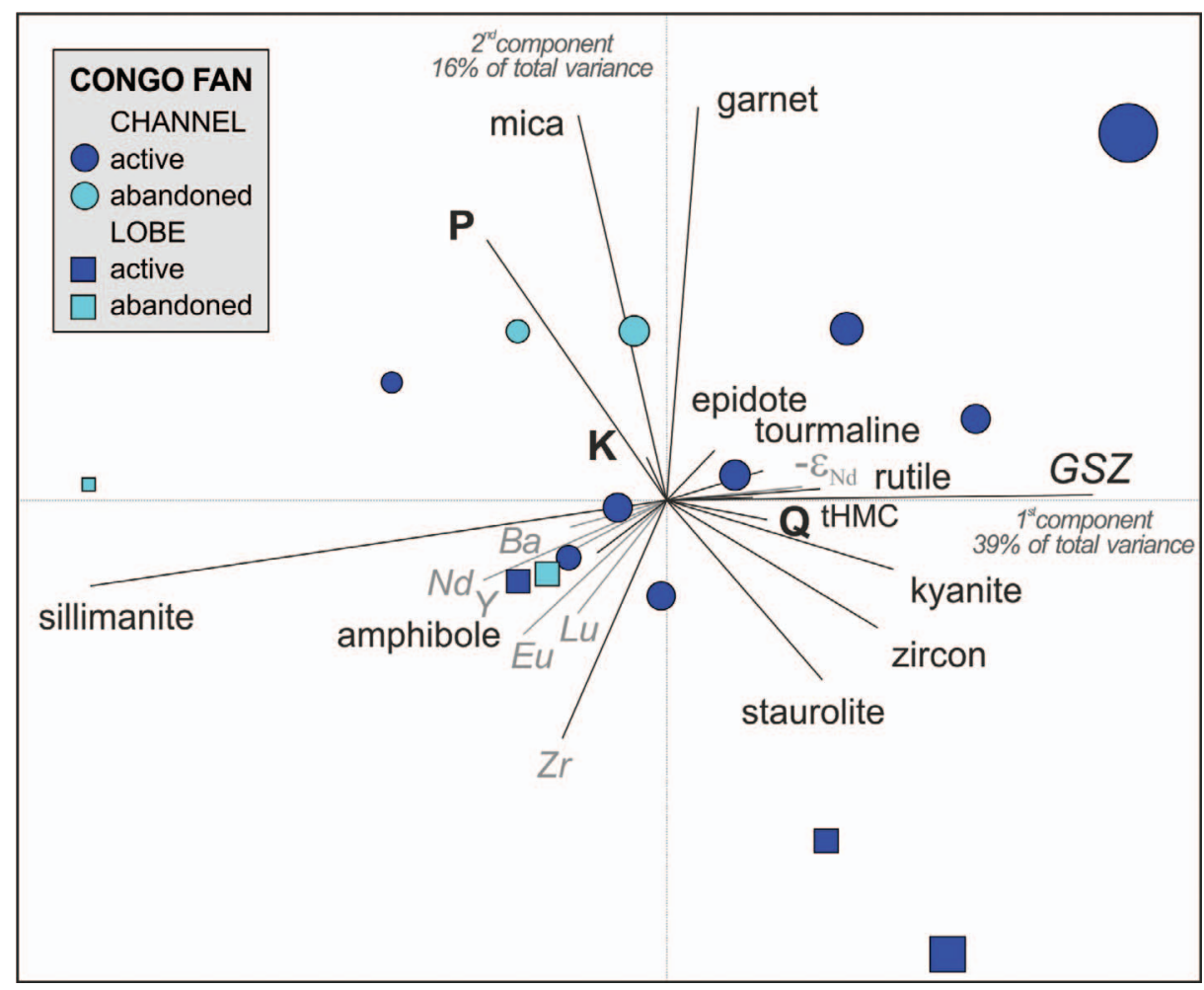

FIG. 7.-Grain-size control on intersample mineralogical and chemical variability (symbol size proportional to sample grain size). Grain size (GSZ) correlates with quartz and most of the denser heavy minerals, and anticorrelates with amphibole, sillimanite, and trace elements. Note that $\varepsilon_{\mathrm{Nd}}$ values are more negative in samples with more quartz and less Nd. The biplot (Gabriel 1971; drawn with CoDaPack software by ComasCufí and Thió-Henestrosa 2011) displays multivariate observations (points) and variables (rays). The length of each ray is proportional to the variance of the corresponding variable; if the angle between two rays is $0^{\circ}$ or $180^{\circ}$, then the corresponding variables are perfectly correlated or anticorrelated. Q, quartz; K, K-feldspar; P, plagioclase; tHMC, transparent heavy mineral concentration. Chemical elements in gray italics.

HREE; the convex-upward HREE pattern suggests that our heavy-mineral analyses failed to detect a mineral present only in traces but very rich in $\mathrm{Y}$ and HREE, as discussed below.

The studied samples, independently of grain size, display a negative $\mathrm{Ce}$ anomaly $\left(\mathrm{Ce} / \mathrm{Ce}^{*} \leq 0.98,0.78\right.$ for 5863$)$ and notably lower $\mathrm{Ce} / \mathrm{La}$ ratios $(\leq 1.95,1.53$ for 5863$)$ than observed in any component of the geochemical flux in the Congo basin (Gaillardet et al. 1995; Dupré et al. 1996). Bayon et al. (2019) reported negative Ce anomalies from suspended load in several Congo tributaries and $\mathrm{Ce} / \mathrm{Ce}^{*}$ values as low as $0.73-0.74$ in the Ubangui and Kasai rivers. In Congo sediments, Ce depletion can be ascribed to REE remobilization in soils followed by preferential incorporation of $\mathrm{Ce}$ into Fe-oxides, as suggested by the marked positive Ce anomalies shown by river-borne oxyhydroxides (Bayon et al. 2004).

\section{Integrating Mineralogical and Geochemical Data}

The combination of mineralogical and geochemical datasets provides a powerful means to investigate the compositional variability of sediments. The relationships between mineralogical and geochemical signatures, however, are hard to determine accurately because chemical elements are contributed in unknown proportions by different detrital minerals, many of them being solid solutions and containing impurities or inclusions.

As a first step (assumption), an average concentration for Y, REE, and $\mathrm{Zr}$ in quartz, feldspars, micas, and heavy minerals was assumed based on an extensive set of chemical analyses compiled from the literature and carried out on pure quartzose sands from Uganda and the Congo and on mineral separates from Ganga-Brahmaputra sediments (Garzanti et al. 2010, 2011).

As a second step (calculation), the concentration of each chemical element was recalculated for each sample based on petrographic and heavy-mineral data.

As a third step (calibration), the comparison between the observed and recalculated element concentrations allowed us to numerically calibrate the weight percentages of accessory minerals such as zircon (the main contributor of $\mathrm{Zr}, \mathrm{Hf}, \mathrm{Yb}$, and $\mathrm{Lu}$ ) and especially monazite and allanite, important contributors of LREE that are too rare to be accurately determined with optical analyses. Point-counting showed allanite to be slightly more abundant in volume than monazite, which is however notably denser; the ratio between the weight percentages of allanite and monazite was thus assessed as $\sim 0.9$. Because quartz has very low trace-element concentration ( $\sim 4 \mathrm{ppm}$ REE overall), its contribution to the REE budget is generally considered marginal for most sediments (e.g., $\leq 2 \%$ in GangaBrahmaputra bedload or suspended load; Garzanti et al. 2010, 2011). However, where quartz is overwhelming and heavy-mineral concentration very poor, as in the special case of Congo sand, quartz contribution in REE becomes relevant and its REE content must thus be assessed carefully.

As a fourth step (evaluation), the residual discrepancies were evaluated. In our case, the recalculated HREE resulted to be insufficient for several samples (especially for 5857), a dearth explained by the undetected presence of a rare yttrium mineral very rich in HREE, which we assumed to be xenotime. After the discrepancy was empirically minimized by a trialand-error approach, the monazite/xenotime weight ratio resulted to be $\sim 5.5$, similar to that observed in Ganga and Brahmaputra sediments.

As a fifth and final step (adjustment), a further refined calibration of element concentrations and mineral abundances allowed us to obtain a satisfactory agreement (all elements in all samples closing between $95 \%$ and $105 \%$, with standard deviation $\leq 10 \%$ ). The assumed trace-element concentrations and the calculated contributions for all significant detrital components are provided in Appendix Table A7.

\section{The REE Budget}

Several detrital components, including both rare ones very rich in REE and abundant ones containing only a few REE, contribute significantly to the REE budget of Congo Fan sediments. Because of its extreme abundance and concurrent scarcity of heavy minerals, quartz unexpectedly resulted to be the principal contributor of REE. For all REE, quartz contribution increases, on average, from $\sim 10 \%$ in silt to $\sim 40 \%$ in 


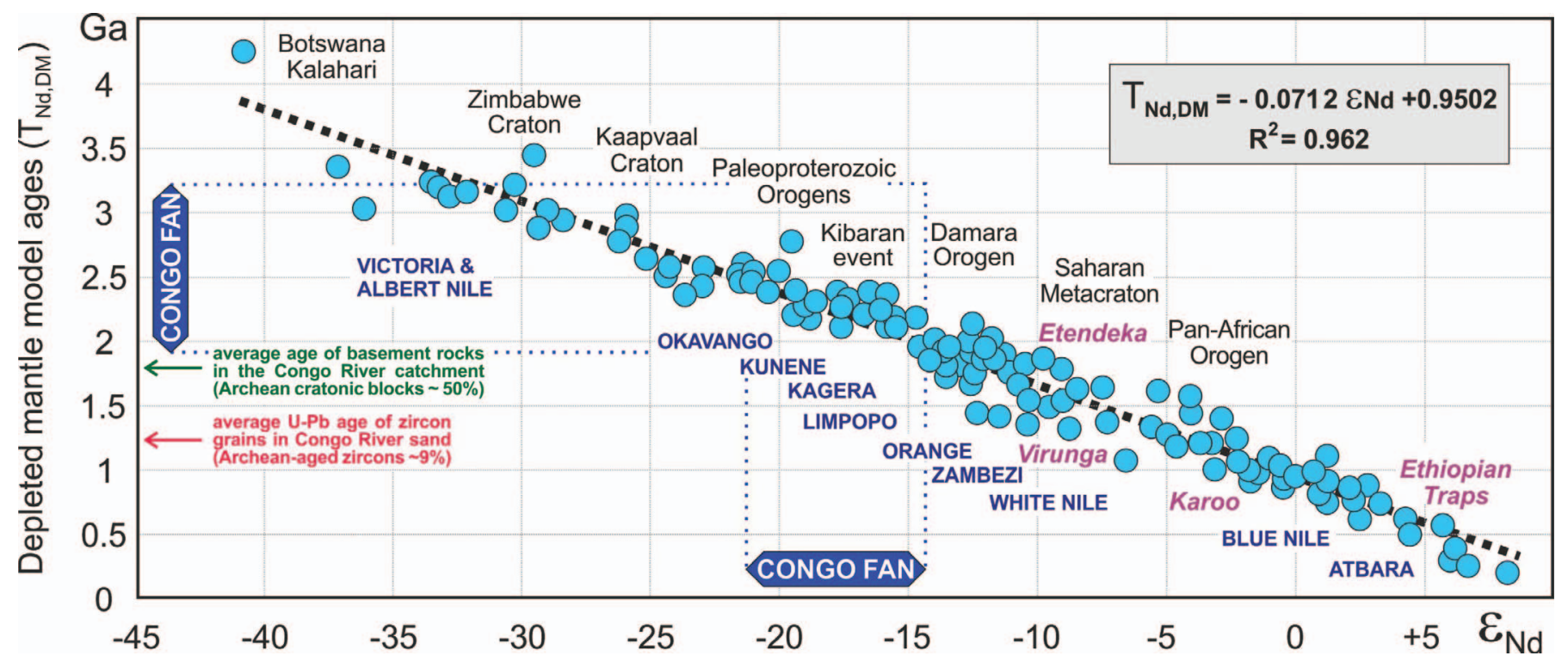

FIG. 8. - Relationship between $\varepsilon_{\mathrm{Nd}(0)}$ values and depleted mantle model ages $\left(\mathrm{T}_{\mathrm{Nd}, \mathrm{DM}}\right)$ for modern African sediments carried by major rivers (indicated in blue) and derived from distinct geological domains (black) including volcanic fields (purple). Data on 134 samples are from Padoan et al. (2011) and Garzanti et al. (2013b, 2014b). In Congo Fan sand, the strong grain-size control on $\varepsilon_{\mathrm{Nd}}$ values is ascribed to mixing of monazite and other $\mathrm{Nd}$ carriers mainly derived from Proterozoic orogenic belts with quartz grains carrying a more negative signature because more durable and thus ultimately derived in larger proportions from Archean cratons.

medium to coarse sand, being minimum for Eu (from $\sim 5 \%$ in silt to $\sim 25 \%$ in coarse sand). Feldspars contribute significantly to the Eu budget. K-feldspar contributes about as much as plagioclase $(\sim 15 \%$ each on average), the latter being richer in Eu but less abundant. Overall, feldspars, phyllosilicates, and rock fragments contribute between 5\% and 10\% each to the REE budget. Among heavy minerals, the main contributors are monazite and allanite for LREE $(\sim 30 \%$ and $\sim 10 \%$ on average, respectively), and zircon for $\mathrm{Yb}$ and $\mathrm{Lu}(40 \%$ and $50 \%$ on average, respectively). Although undetected in heavy-mineral analyses, xenotimepossibly present as inclusions - may supply up to $10-15 \%$ of Y and HREE. Other significant contributors are estimated to be epidote and opaque FeTi-Cr oxides $(5-10 \%$ each), whereas garnet, titanite, and apatite are too scarce and amphibole too poor in REE to supply more than $1 \%$ each on average. Tourmaline, rutile, and aluminum nesosilicates are insignificant contributors to the REE budget.

\section{Controls on the Variability of $\varepsilon_{N d}$ Values}

Congo Fan sediments display a clear correlation between $\varepsilon_{\mathrm{Nd}}$ values and grain size (Fig. 6). This indicates that the Nd-bearing minerals preferentially concentrated in coarser samples carry a more negative $\varepsilon_{\mathrm{Nd}}$ signature than Nd-bearing minerals preferentially concentrated in finer samples.

The calculations illustrated above suggest that, in the studied samples, $\mathrm{Nd}$ is contributed a good half on average by heavy minerals (mainly monazite, subordinately allanite and epidote), and a quarter each by quartz and by other detrital components (feldspars, phyllosilicates, and rock fragments). Nd contribution by quartz increases from $5-10 \%$ in silt and $15-20 \%$ in finest sand samples $\left(\varepsilon_{\mathrm{Nd}}\right.$ from -15 to -16$)$ to $40-50 \%$ in coarsest sand samples $\left(\varepsilon_{\mathrm{Nd}}\right.$ from -19 to -21$)$, whereas the $\mathrm{Nd}$ contribution by monazite, allanite, and epidote drops from $60-65 \%$ in silt and $45-50 \%$ in finest sand samples to $5-15 \%$ in coarsest sand samples. We conclude that quartz and heavy minerals carry a different $\varepsilon_{\mathrm{Nd}}$ signature, most negative for quartz $(<-21)$ and least negative for monazite, allanite, and epidote $(\geq-15)$.

The $\varepsilon_{\mathrm{Nd}}$ values of sediments generated in the African continent are most negative for detritus shed from Archean shields $\left(\varepsilon_{\mathrm{Nd}}\right.$ from -25 to -40$)$ and become progressively less negative for detritus shed from surrounding Paleoproterozoic $\left(\varepsilon_{\mathrm{Nd}}\right.$ mainly around -20$)$, Mesoproterozoic $\left(\varepsilon_{\mathrm{Nd}}\right.$ mainly around -15$)$, and Neoproterozoic geological domains $\left(\varepsilon_{\mathrm{Nd}}\right.$ from $\leq-10$ to $\geq-5$ ) (Fig. 8). We may thus conclude that the ultimate source rocks are on average older for quartz grains (largely Archean) than for heavy minerals and other detrital components (mostly Proterozoic). This can be explained by the higher mechanical and chemical durability of quartz grains, that resisted multiple sedimentary cycles of weathering, transport, and diagenesis through geological time better than any other detrital mineral. Even zircon proves not to be equally resistant to multiple recyclings. Congo sediments are characterized by polymodal $\mathrm{U}-\mathrm{Pb}$ zircon-age spectra with major clusters at $\sim 600, \sim 1000, \sim 2000$, and $\sim 2600$ Ma, with a mean age of $1225 \pm 130 \mathrm{Ma}$ (Garzanti et al. 2019a). Although the Congo drainage basin is surrounded by Neoarchean to Paleoarchean cratonic blocks (Fig. 1), Archean U-Pb ages represent only $9 \%$ of total zircon grains in Congo River sand, which suggests that a significant part of the oldest zircons, most likely those richer in radiogenic $U$ and $T h$ and thus highly metamict, were selectively destroyed during multiple sedimentary cycles. Old and strongly metamict zircons have long been proved to be highly susceptible to weathering and efficiently destroyed under acid $\mathrm{pH}$ conditions met in many types of soils, including podzol and laterite (e.g., Colin et al. 1993; Balan et al. 2001; Malusà et al. 2013; Resentini et al. 2020). If the average age of zircon grains is late Mesoproterozoic, then it is reasonable to assume that the average age of ultimate source rocks for less durable monazite, allanite, and epidote cannot be older, which corroborates our inference that they carry an average $\varepsilon_{\mathrm{Nd}}$ value $\geq-15$ versus an average $\varepsilon_{\mathrm{Nd}}$ value $<-21$ for quartz.

The marked grain-size dependence of $\varepsilon_{\mathrm{Nd}}$ values in Congo Fan sediments is thus explained by the concentration of durable quartz grains carrying the most negative $\varepsilon_{\mathrm{Nd}}$ signature in coarser samples, whereas notably lower $\varepsilon_{\mathrm{Nd}}$ signatures characterize finer-grained detrital components including clay. Over the last $10 \mathrm{kyr}$, clay deposited in the Congo Canyon has maintained $\varepsilon_{\mathrm{Nd}}$ values of $-15.6 \pm 0.1$, suggesting that relative sediment supply from the major Congo River branches $\left(\varepsilon_{\mathrm{Nd}}-11.4 \pm 0.2\right.$, $-15.5 \pm 0.7$, and $-17.6 \pm 0.4$ for the Lualaba, Kasai, and Ubangui, 


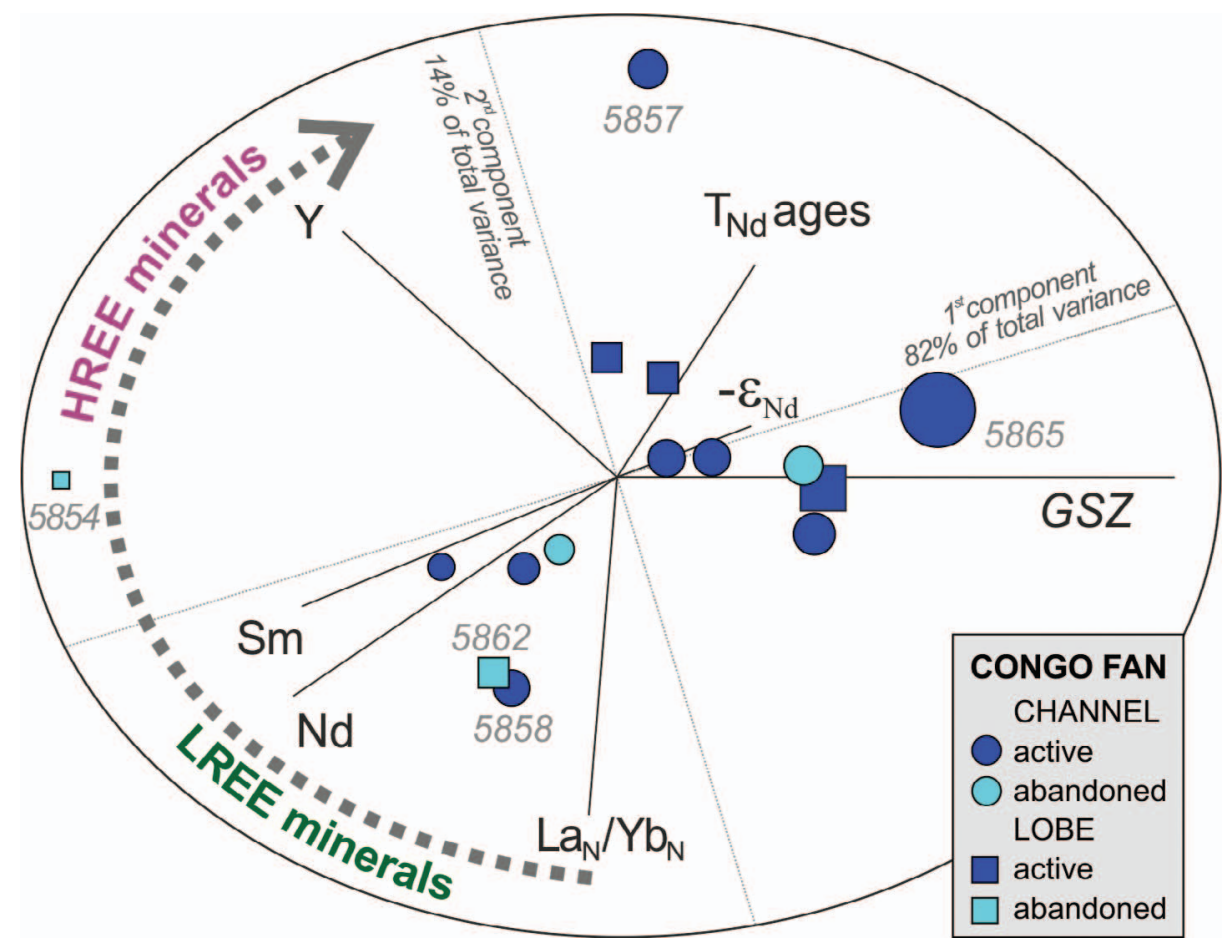

FIG. 9.--Investigating controls on isotope ratios and $\mathrm{T}_{\mathrm{Nd}}$ model ages (symbol size proportional to sample grain size). Besides the effects of grain size and quartz abundance $\left(\varepsilon_{\mathrm{Nd}}\right.$ values are more negative and $\mathrm{T}_{\mathrm{Nd}}$ model ages older in coarser quartz-rich samples with less $\mathrm{Nd}$ ), $\mathrm{T}_{\mathrm{Nd}}$ model ages are much lower in samples 5858 and 5862 enriched in LREE minerals (monazite and allanite) than in sample 5857 enriched in HREE minerals (presumably xenotime). respectively) has not drastically changed throughout the Holocene (Bayon et al. 2019).

\section{Controls on the Variability of $T_{N d}$ Model Ages}

The observed marked variability of $\varepsilon_{\mathrm{Nd}}$ values and $\mathrm{T}_{\mathrm{Nd}}$ model ages is not controlled exclusively by grain size. The different $\mathrm{Sm} / \mathrm{Nd}$ signature of different detrital components plays a major role. The $\mathrm{Sm} / \mathrm{Nd}$ ratio is estimated to be $\sim 0.20$ for quartz, K-feldspar, and mica, slightly lower for LREE-rich minerals ( $\sim 0.19$ for monazite, $\sim 0.13$ for allanite), slightly higher for MREE-bearing and HREE-bearing minerals ( $\sim 0.24$ for titanite, $\sim 0.26$ for apatite and epidote, $\sim 0.28$ for amphibole, $\sim 0.29$ for garnet), but much higher for HREE-rich minerals ( $\sim 1.0$ for zircon and xenotime). As a consequence, samples 5858 and 5862, which contain more monazite and/or allanite as indicated by their steepest REE pattern and most negative Eu anomaly (Fig. 5), yielded $\mathrm{T}_{\mathrm{Nd}, \mathrm{CHUR}}$ and $\mathrm{T}_{\mathrm{Nd}, \mathrm{DM}}$ model ages younger by 1.2-1.4 Ga than sample 5857 (Table 2), which is presumed to contain a rare yttrium mineral (most likely xenotime) as suggested by the convexupward HREE pattern (Fig. 9).

\section{TRACING SEDIMENT MINERALOGY FROM LAND TO SEA}

An amazing fact of the Congo source-to-sink system is that the river has no delta. Congo River sediments are not distributed widely across the continental terrace but, starting tens of kilometers upstream of the coast, they are efficiently funneled through the Congo Canyon and transported directly as gravity flows over more than $1000 \mathrm{~km}$ to feed the vast Congo Fan (Fig. 2). In this section, we compare the mineralogical signatures of Congo River and Congo Fan sands with those of sediments drifting along the coast of northernmost Angola and deposited offshore to investigate provenance and sediment dispersal from the Congo mouth to the deep sea.

\section{Congo River Sand}

Congo River sand upstream of the Soyo estuary is pure quartzose, with mainly well rounded to subrounded monocrystalline quartz commonly displaying abraded overgrowths, a few feldspar grains, and rare fragments of quartzose siltstone, granitoid, and low-rank to high-rank metasedimentary rocks (Garzanti et al. 2019a). Mica is negligible and carbonate grains are virtually lacking. The very poor tHM suite mainly includes zircon, tourmaline and rutile, with epidote, staurolite, amphibole, garnet, and kyanite. Compositional differences between Congo River and Congo Fan sand are minor (Fig. 4). The variability of petrographic modes appears to be slightly less for turbidite sand, where mica flakes are few but slightly more common than in river sand.

\section{Longshore Sand Dispersal}

The entire coast of southwestern Africa as far north as the Gulf of Guinea is swept by powerful northward longshore currents driven by swells originating from persistent stormy winds in the Southern Ocean. Sand transport is continuous along the broad inner shelf offshore Namibia (Garzanti et al. 2012a, 2014c) and becomes discontinuous in Angola, where sand spits develop to the north of major river outlets (Dinis et al. 2016) but northward-drifting sand is locally captured by canyons where they cut across the narrow shelf and reach close to shore (Garzanti et al. 2018b).

Sand generated in northernmost Angola is quartzose with K-feldspar $\geq$ plagioclase and very few lithic fragments (Garzanti et al. 2018a). The moderately rich tHM suite includes epidote, amphibole, and garnet, with kyanite and very minor zircon, tourmaline, rutile, and staurolite. Mineralogical signatures (e.g., steady northward increase in the ZTR index; Fig. 10) indicate that sand entrained by longshore currents gets progressively mixed with Congo sand as the Soyo estuary is approached. Littoral-drifting sand enters the estuary from the south and forms the spit that harbors the city of Soyo. On the inner shelf just south of the Congo mouth (site GEOB1004 in Fig. 10), fine quartzose sand is mixed with brown goethite ooids, whereas very fine sand north of the mouth contains brown pellets and foraminifera exclusively (site GEOB1001 in Fig. 10). Longshore transport is thus interrupted at the Congo mouth, where northward-drifting sand is all captured in the canyon and conveyed to the deep sea. 


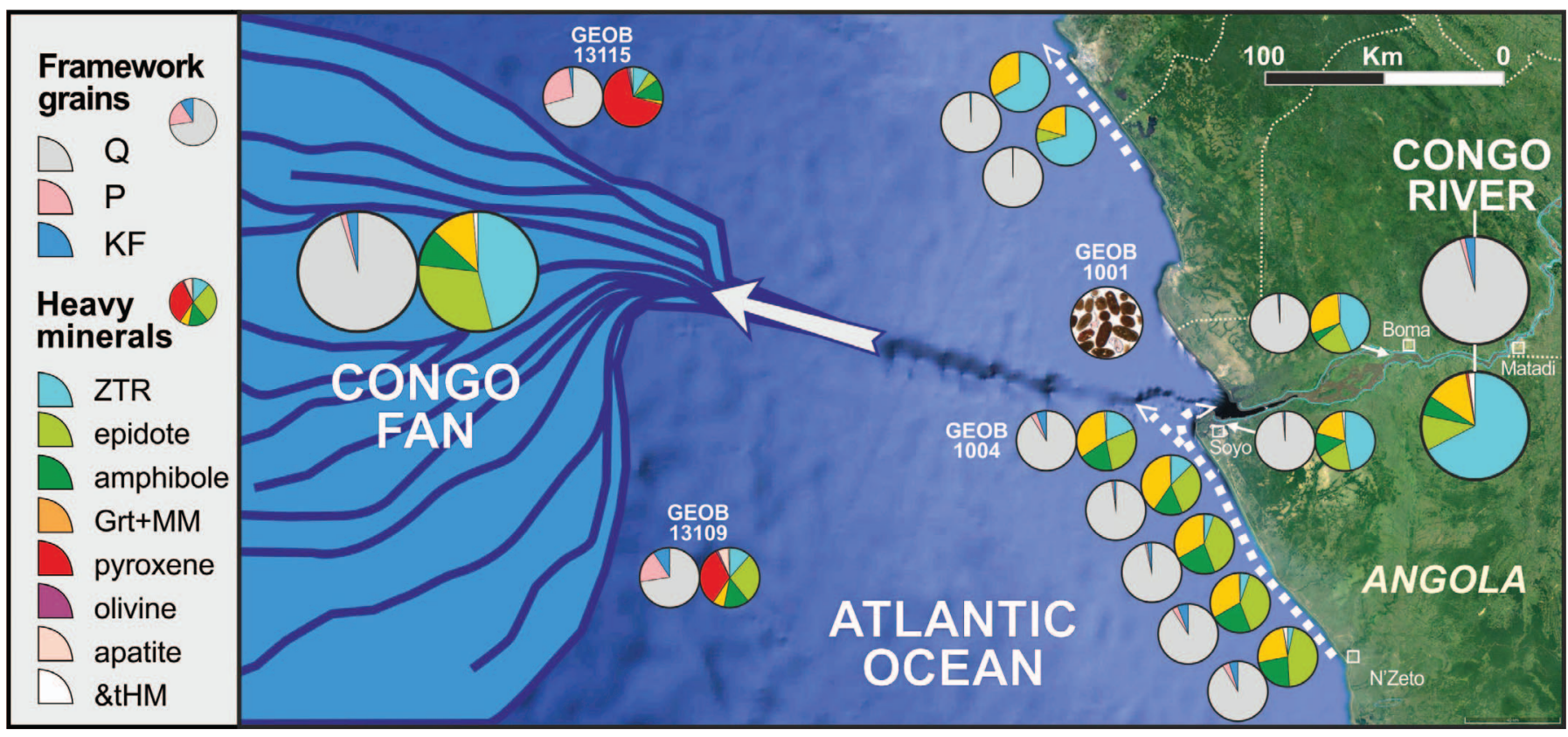

FIG. 10.- Sediment dispersal from equatorial Africa to the Atlantic Ocean. Mineralogical signatures indicate that sand richer in epidote and amphibole drifting northward along the coast of northernmost Angola (dotted line with arrows) progressively mixes with sediment richer in quartz and ZTR minerals supplied by the Congo River, is traced for $\sim 70 \mathrm{~km}$ in the Soyo estuary, and is eventually caught in the canyon and flushed toward the deep sea, where it is estimated to represent $7 \pm 2 \%$ of turbidite deposits. On the inner shelf north of the Congo mouth, sediment consists entirely of pellets and a few forams (site GEOB1001). Deep-sea mud mantling the slope on either side of the canyon is enriched in plagioclase and contains volcanic-derived pyroxenes, oxy-hornblende, and olivine (sites GEOB13109 and GEOB13115; data for river, estuary, shelf, and slope sediments after Garzanti et al. 2019a).

\section{Deep-Sea Mud}

Offshore of the Congo mouth at water depths between 2000 and $3000 \mathrm{~m}$ b.s.l., the sediment apron mantling the continental slope mostly consists of authigenic and biogenic particles (glaucony, bioclasts, pellets, organic matter, pyrite, a few phosphate grains). The minor $(\leq 6 \%)$ silt-size siliciclastic fraction is feldspatho-quartzose, with more feldspar than in Congo River sediments and plagioclase $>$ K-feldspar. Such differences can be largely explained by preferential concentration of feldspars and especially plagioclase in silt. The tHM suites, however, are radically different and include epidote, hypersthene, augitic clinopyroxene, and amphibole with rare oxy-hornblende south of the Congo Canyon, and mostly green augite and hypersthene with subordinate oxy-hornblende north of the canyon (Fig. 10).

\section{Provenance Budgets}

Sediments are mixtures of detrital populations supplied by different sources and thus characterized by different composition and grain size. The accurate assessment of the proportional supply from each of these sources requires that their end-member compositional signatures are defined by a wide set of parameters that are both precisely determined and sufficiently distinct. Natural cases are intrinsically complex and, in order to reduce uncertainties, this procedure necessarily involves a series of calculations performed according to a range of plausible criteria (Garzanti et al. 2012b; Resentini et al. 2017).

The Congo Fan can be envisaged as a relatively simple system fed mostly by the Congo River and partly by northward-drifting littoral sand, which includes additional supply from locally strong coastal erosion in northernmost Angola as evidenced by up to several meters-high scarps in the backshore. By combining the mineralogical fingerprints of these two sources with new data on deep-sea-fan deposits we can assess the proportional contribution from each source to diverse parts of the sedimentary system, including northernmost Angola beaches, the Soyo estuary, the shelf offshore, and the Congo Fan.

To this goal, the 15 newly studied samples showing only limited intersample mineralogical variability can be considered as replicates, thus allowing us to obtain a precise definition of the average mineralogical fingerprint of Congo Fan turbidites. Overwhelming quartz abundance, strongly grain-size-dependent feldspar content, and very poor heavymineral concentration represent instead unfavorable conditions. The heavymineral spectrum offers firm clues, but a precise translation of the heavymineral provenance budget into a total provenance budget requires a very accurate determination of heavy-mineral concentration in all end-member sources.

Sand composition generated in northern Angola is precisely defined by mineralogical parameters $(\mathrm{Q} / \mathrm{F} 10.1 \pm 0.5$; tHMC $2.2 \pm 0.1$; ZTR $5 \pm 2)$, relatively high epidote $(38 \pm 11 \% \mathrm{tHM})$, amphibole $(28 \pm 7 \% \mathrm{tHM})$, garnet $(21 \pm 4 \% \mathrm{tHM})$, and kyanite $(7 \pm 2 \% \mathrm{tHM})$, and low staurolite $(1 \pm$ $1 \% \mathrm{tHM})$ and sillimanite ( $0 \% \mathrm{tHM})$. Congo River sand has a different fingerprint (Q 89-98\%QFL and F 1-9\%QFL; tHMC $0.2 \pm 0.1$; ZTR 67 $\pm 2)$, lower epidote $(11 \pm 1 \% \mathrm{tHM})$, amphibole $(6 \pm 2 \% \mathrm{tHM})$, garnet $(3 \pm 1 \% \mathrm{tHM})$, kyanite $(4 \pm 3 \% \mathrm{tHM})$, and higher staurolite $(4 \pm 3 \% \mathrm{tHM})$ and sillimanite $(2 \pm 1 \% \mathrm{tHM})$.

Along the northernmost Angolan coast, a progressive northward increase of sand originally derived from the Congo River is robustly indicated by the steady northward increase of $\mathrm{Q} / \mathrm{F}$ ratio (up to 47 in beaches and to 70-73 inside the Soyo estuary), ZTR index (up to 13 in beaches and to 44-47 inside the Soyo estuary), staurolite and sillimanite, with parallel progressive decrease in epidote, amphibole, and garnet. From $\sim 70 \mathrm{~km}$ to $\sim 40 \mathrm{~km}$ and next to $\sim 20 \mathrm{~km}$ south of the river mouth, the proportion of Congo-derived sand is calculated to increase from zero to 34 $\pm 10 \%$ and next to $68 \pm 4 \%$. Littoral-drifting sand generated in northern Angola is estimated to represent $28 \pm 4 \%$ of the siliciclastic fraction on the inner shelf $\sim 16 \mathrm{~km}$ offshore of the mouth. Influence of coastal sand is 
traced also inside the Soyo estuary for as much as $\sim 70 \mathrm{~km}$, where it is estimated to represent $\sim 8 \%$ of Soyo beach and still $\sim 5 \%$ nearly as far as Boma, suggesting local reworking of Quaternary or even older coastal deposits delivered by a precursor of the modern littoral system. The homogeneous mineralogy of Congo Fan turbidites indicates that littoraldrifting sand generated in northern Angola is regularly captured in the Congo Canyon and is estimated to constantly contribute $7 \pm 2 \%$ of detritus to the sediment flux funneled toward the deep sea.

Fine silt deposited on the continental slope on both sides of the Congo Canyon is estimated to be fed largely from the Congo River (65-70\%) with contribution from littoral-drifting sediment significant only south of the canyon $(\sim 20 \%)$. Common clinopyroxene and orthopyroxene locally associated with oxy-hornblende and minor olivine reveal additional contribution from distant volcanic sources, estimated to increase from $\sim 15 \%$ south of the canyon to $25-30 \%$ north of the canyon (Fig. 10). Greater abundance of volcaniclastic detritus in the north suggests that the source of ash fall may be represented by the Cameroon Line (Fig. 1) and most plausibly by its continental sector where explosive eruptions are more frequent (Njome and de Wit 2014).

\section{CONCLUSIONS}

The Congo Fan is the largest turbidite cone on Earth fed entirely with anorogenic detritus. The quartzose to pure quartzose signature of its sediments is unique among all major source-to-sink systems, and reflects multiple recyclings coupled with extreme chemical weathering in cratonic equatorial Africa. In this study, we have documented the mineralogical and geochemical fingerprints of Congo Fan turbidites and compared them to sand of the Congo River and coastal northern Angola to shed new light on processes of sediment generation and dispersal.

Congo Fan turbidites are characterized by fairly homogeneous quartzdominated composition and invariably very poor transparent heavy-mineral suites including epidote, zircon, and tourmaline associated with amphibole, rutile, staurolite, kyanite, garnet, and sillimanite. Mineralogical variability is largely grain-size dependent and mainly testified by the concentration of detrital quartz in coarser samples and size classes. Most marked is the intrasample mineralogical variability displayed by finer-grained samples, where Raman counting of different size classes documented a systematic concentration of feldspar grains in the fine tail of the size distribution ascribed to their good cleavability coupled with greater susceptibility to weathering. The progressive increase of feldspars relative to quartz, of orthoclase relative to microcline, and of plagioclase relative to K-feldspar with decreasing grain size reflects the expected order of chemical durability of detrital tectosilicates, and their consequently different ability to survive intense equatorial weathering in the present sedimentary cycle as well as repeated cycles of weathering and diagenesis through geological time.

Intersample compositional variability is best revealed by trace elements preferentially hosted in the densest detrital minerals monazite and zircon (i.e., REE, Zr, Hf). Because of their very low amount in Congo Fan sediments, however, heavy minerals do not dominate the REE budget. Despite its very low content in trace elements, quartz is so abundant that it accounts for nearly a quarter of the REE on average and for up to $40-50 \%$ of $\mathrm{Nd}$ in coarser samples. Only monazite and zircon are estimated to contribute more LREE and heaviest REE ( $\mathrm{Yb}$ and $\mathrm{Lu}$ ) than quartz, respectively, whereas titanite, apatite, garnet, and amphibole are too scarce to contribute more than $1 \%$ of the REE each.

Grain-size-dependent intersample variability is most manifest for $\varepsilon_{\mathrm{Nd}}$ values $\left(\mathrm{R}^{2}\right.$ 0.74). In these sediments mostly derived from Precambrian rocks of cratonic Africa, $\varepsilon_{\mathrm{Nd}}$ ranges widely from -14.8 in silt, which is richer in detrital components other than quartz, to -21.2 in quartzdominated coarse sand. The positive relationship between the grain-sizedependent variabilities of quartz and $\varepsilon_{\mathrm{Nd}}$ values indicates that quartz carries on average a more strongly negative $\varepsilon_{\mathrm{Nd}}$ signature than other $\mathrm{Nd}$ carriers, including monazite. This is chiefly ascribed to the great mechanical and chemical durability of monocrystalline quartz and its consequent chances of surviving even multiple sedimentary cycles better than any other mineral. It is thus inferred that quartz carries the most strongly negative isotopic signal because it is derived-largely indirectly through repeated recycling - in greater proportions from Archean basements than all other detrital minerals including zircon, for which U-Pb data indicate mostly Neoproterozoic and Orosirian ages with a dearth of Archean grains (Garzanti et al. 2019a).

Neodymium isotope values and model ages are not influenced solely by grain size and quartz abundance but also by different REE spectra of detrital components, and samples enriched in LREE minerals (monazite and allanite) display late Calymmian $\mathrm{T}_{\mathrm{Nd}, \mathrm{CHUR}}$ and Orosirian $\mathrm{T}_{\mathrm{Nd}, \mathrm{DM}}$ model ages, whereas the sample most enriched in HREE minerals (plausibly xenotime, possibly present as inclusion) yielded 1.2-1.4 Ga older, Mesoarchean $\mathrm{T}_{\mathrm{Nd}, \mathrm{CHUR}}$ and Paleoarchean $\mathrm{T}_{\mathrm{Nd}, \mathrm{DM}}$ model ages.

The accurate definition of compositional fingerprints in the Congo sedimentary system allowed us to assess that sand generated in northern Angola is entrained by the longshore currents that characterize the entire Atlantic coast of southwestern Africa, and mixes with sand supplied by the Congo River in proportions that increase northward reaching $\sim 70 \%$ on the inner shelf in front of the mouth. Littoral-drifting sand enters the estuary and is recorded as far as $\sim 70 \mathrm{~km}$ inland, being eventually captured in the Congo canyon and funneled toward the deep ocean where it is estimated to represent $7 \pm 2 \%$ of turbidite sand. The detailed mineralogical and geochemical study of sediments and of their intersample and intrasample compositional variability offers an effective key to quantitatively unravel the complex processes of detrital production and dispersal from the continents to the deep ocean.

\section{ACKNOWLEDGMENTS}

We are deeply thankful to JSR reviewer Tim Lawton and an anonymous reviewer for their excellent critical advice and to JSR Editor Kathleen M. Marsaglia and Associate Editor Andrea Fildani for careful handling of our manuscript. An earlier version of this article received extensive comments generously provided by Oleg S. Pokrovsky, Catherine Jeandel, and another two anonymous reviewers. We heartily thank Sergio Andò for precious advice concerning heavy-mineral separation and Raman spectroscopy analyses. Funding was contributed by Project MIUR-Dipartimenti di Eccellenza 20182022, Department of Earth and Environmental Sciences, University of MilanoBicocca. We are grateful to the French Oceanographic Fleet, to captains, crews, and chief scientists of ZAIANGO1, ZAIANGOROV, REPREZAI, and CONGOLOBE cruises, and to IFREMER and TOTAL, for giving access to samples. Particular thanks are due to the technical staff of IFREMER's Laboratoire Géodynamique et enregistrement Sédimentaire and CREAM (Centre de Ressources en Echantillons et Archives Marins) marine sediment and rock repository (https://wwz.ifremer.fr/echantillons).

\section{SUPPLEMENTAL MATERIALS}

Supplemental data is available frm the SEPM Data Archive, https://www. sepm.org/supplemental-materials. This includes detailed information on sampling sites (Table A1), grain-size data (Table A2), petrographic data (Table A3), heavy-mineral data (Table A4) with frequency of corrosion features (Table A5), geochemical data (Table A6), and the assumed trace-element concentrations and calculated mineral contributions to the geochemical budget (Table A7).

\section{REFERENCES}

Alsdorf, D., Beighley, E., Laraque, A., Lee, H., Tshimanga, R., O’Loughlin, F., Mahé, G., Dinga, B., Moukandi, G., And Spencer, R.G.M., 2016, Opportunities for hydrologic research in the Congo Basin: Reviews of Geophysics, v. 54, p. 378-409. 
ANDò, S., 2020, Gravimetric separation of heavy-minerals in sediments: Minerals, v. 10, no. 273 , doi:10.3390/min10030273.

Andò, S., Vignola, P., And Garzanti, E., 2011, Raman counting: a new method to determine provenance of silt: Rendiconti Lincei Scienze Fisiche e Naturali, v. 22, p. 327 347.

Andò, S., Garzanti, E., Padoan, M., and Limonta, M., 2012, Corrosion of heavy minerals during weathering and diagenesis: a catalog for optical analysis: Sedimentary Geology, v. 280 , p. $165-178$.

Andò, S., Aharonovich, S., Hahn, A., George, S.C., Clift, P.D., and Garzanti, E., 2019, Integrating heavy-mineral, geochemical, and biomarker analyses of Plio-Pleistocene sandy and silty turbidites: a novel approach for provenance studies (Indus Fan, IODP Expedition 355): Geological Magazine, v. 157, p. 929-938, doi:10.1017/S001675681 9000773.

Anka, Z., Séranne, M., Lopez, M., Scheck-Wenderoth, M., and Savoye, B., 2009, The long-term evolution of the Congo deep-sea fan: a basin-wide view of the interaction between a giant submarine fan and a mature passive margin (ZaiAngo project): Tectonophysics, v. 470, p. 42-56.

AnKa, Z., Séranne, M., And Di Primio, R., 2010, Evidence of a large upper-Cretaceous depocentre across the continent-ocean boundary of the Congo-Angola basin Implications for palaeo-drainage and potential ultra-deep source rocks: Marine and Petroleum Geology, v. 27, p. 601-611.

Azpiroz-Zabala, M., Cartigny, M.J., Talling, P.J., Parsons, D.R., Sumner, E.J., Clare, M.A., Simmons, S.M., Cooper, C., And Pope, E.L., 2017, Newly recognized turbidity current structure can explain prolonged flushing of submarine canyons: Science Advances, v. 3, doi:10.1126/sciadv.1700200.

Babonneau, N., Savoye, B., Cremer, M., And Klein, B., 2002, Morphology and architecture of the present canyon and channel system of the Zaire deep-sea fan: Marine Geology, v. 19 , p. 445-467.

Babonneau, N., Savoye, B., Cremer, M., and Bez, M., 2010, Sedimentary architecture in meanders of a submarine channel: detailed study of the present Congo turbidite channel (Zaiango project): Journal of Sedimentary Research, v. 80, p. 852-866.

Balan, E., Neuville, D.R., Trocellier, P., Fritsch, E., Muller, J.P., and Calas, G., 2001, Metamictization and chemical durability of detrital zircon: American Mineralogist, v. 86, p. $1025-1033$.

Barrat, J.A., Zanda, B., Moynier, F., Bollinger, C., Liorzou, C., and Bayon, G., 2012, Geochemistry of $\mathrm{CI}$ chondrites: major and trace elements, and $\mathrm{Cu}$ and $\mathrm{Zn}$ isotopes: Geochimica et Cosmochimica Acta, v. 83, p. 79-92.

Basu, A., 1976, Petrology of Holocene fluvial sand derived from plutonic source rocks: implications to paleoclimatic interpretation: Journal of Sedimentary Petrology, v. 46, p 694-709.

Bayon, G., German, C.R., Boella, R.M., Milton, J.A., Taylor, R.N., and Nesbitt, R.W. 2002, An improved method for extracting marine sediment fractions and its application to $\mathrm{Sr}$ and $\mathrm{Nd}$ isotopic analysis: Chemical Geology, v. 187, p. 179-199.

Bayon, G., German, C.R., Burton, K.W., Nesbitt, R.W., and Rogers, N., 2004, Sedimentary $\mathrm{Fe}-\mathrm{Mn}$ oxyhydroxides as paleoceanographic archives and the role of aeolian flux in regulating oceanic dissolved REE: Earth and Planetary Science Letters, v. 224, p. 477-492.

Bayon, G., Barrat, J.-A., Etoubleau, J., Benoit, M., Bollinger, C., and Révillon, S., 2009, Determination of rare earth elements, $\mathrm{Sc}, \mathrm{Y}, \mathrm{Zr}, \mathrm{Ba}, \mathrm{Hf}$ and $\mathrm{Th}$ in geological samples by ICP-MS after Tm addition and alkaline fusion: Geostandards and Geoanalytical Research, v. 33, p. 51-62.

Bayon, G., Schefuß, E., Dupont, L., Borges, A.V., Dennielou, B., Lambert, T., Mollenhauer, G., Monin, L., Ponzevera, E., Skoniecznya, C., And André, L., 2019 The roles of climate and human land-use in the late Holocene rainforest crisis of Central Africa: Earth and Planetary Science Letters, v. 505, p. 30-41.

Blatt, H., 1967, Provenance determinations and recycling of sediments: Journal of Sedimentary Petrology v. 37, p. 1031-1044.

Borromeo, L., Andò, S., France-Lanord, C., Coletti, G., Hahn, A., and Garzanti, E., 2019, Provenance of Bengal Shelf sediments: 1 . Mineralogy and geochemistry of silt: Minerals, v. 9, no. 640, doi:10.3390/min9100640.

Bouvier, A., Vervoort, J.D., And Patchett, P.J., 2008, The Lu-Hf and Sm-Nd isotopic composition of CHUR: constraints from unequilibrated chondrites and implications for the bulk composition of terrestrial planets: Earth and Planetary Science Letters, v. 273, p $48-57$.

Braga, E.S., Andrié, C., Bourès, B., Van Griesheim, A., Baurand, F., and Chuchla, R., 2004, Congo River signature and deep circulation in the eastern Guinea Basin: Deep-Sea Research I, v. 51, p. 1057-1073.

Breyer, J.A., AND BART, H.A., 1978, The composition of fluvial sands in a temperate semiarid region: Journal of Sedimentary Petrology, v. 48, p. 1311-1320.

Broz, M.E., CooK, R.F., AND Whitney, D.L., 2006, Microhardness, toughness, and modulus of Mohs scale minerals: American Mineralogist, v. 91, p. 135-142.

Bultot, F., 1971, Atlas Climatique du Bassin Congolais: Publications de L'Institut National pour L'Etude Agronomique du Congo (I.N.E.A.C.), Deuxieme Partie, Les Composantes du Bilan d'Eau.

CGMW-BRGM, 2016, Geological Map of Africa, 1:10 million scale, Thiéblemont, D., et al., eds., www.brgm.fr.

ClifT, P.D., 2017, Cenozoic sedimentary records of climate-tectonic coupling in the Western Himalaya: Progress in Earth and Planetary Science, v. 4, doi:10.1186/s40645-01 7-0151-8.
Colin, F., Alarcon, C., and Vieillard, P., 1993, Zircon: an immobile index in soils?: Chemical Geology, v. 107 , p. 273-276.

Comas-Cufi, M., and Thió-Henestrosa, F.S., 2011, CoDaPack 2.0: a stand-alone, multiplatform compositional software, in Egozcue, J.J., Tolosana-Delgado, R., and Ortego, M.I., eds., 4th International Workshop on Compositional Data Analysis: Proceedings, www.compositionaldata.com/codapack.php.

Denamiel, C., Budgell, W.P., and Toumi, R., 2013, The Congo River plume: impact of the forcing on the far-field and near-field dynamics: Journal of Geophisical Research, Oceans, v. 118, p. 964-989.

Dennielou, B., Droz, L., Babonneau, N., Jace, C., Bonnel, C., Picot, M., Le Saout, M., Saout, Y., Bez, M., Savoye, B., Olu, K., And Rabouille, C., 2017, Morphology, structure, composition and build-up processes of the active channel-mouth lobe complex of the Congo deep-sea fan with inputs from remotely operated underwater vehicle (ROV) multibeam and video surveys: Deep Sea Research Part II, Topical Studies in Oceanography, v. 142, p. 25-49.

DePaolo, D.J., 1981, Neodymium isotopes in the Colorado Front Range and crust-mantle evolution in the Proterozoic: Nature, v. 291(5812), p. 193-196.

Dickinson, W.R., 1985, Interpreting provenance relations from detrital modes of sandstones, in Zuffa, G.G., ed., Provenance of Arenites: Reidel, Dordrecht, NATO ASI Series, v. 148 , p. 333-361

Dinis, P.A., Huvi, J., Cascalho, J., Garzanti, E., Vermeesch, P., and Callapez, P., 2016, Sand-spits systems from Benguela region (SW Angola). An analysis of sediment sources and dispersal from textural and compositional data: Journal of African Earth Sciences, v. 117, p. 171-182.

Dinis, P., Garzanti, E., Vermeesch, P., and Huvi, J., 2017, Climatic zonation and weathering control on sediment composition (Angola): Chemical Geology, v. 467, p. $110-121$.

Dinis, P.A., Garzanti, E., Hahn, A., Vermeesch, P., and Pinto, M.C., 2020, Weathering indices as climate proxies. A step forward based on Congo and SW African river muds: Earth-Science Reviews, v. 201, 103039, doi:10.1016/j.earscirev.2019.103039.

Doтт, R.H., 2003, The importance of eolian abrasion in supermature quartz sandstones and the paradox of weathering on vegetation-free landscapes: The Journal of Geology, v. 111, p. $387-405$.

Droz, L., Marsset, T., Ondreas, H., Lopez, M., Savoye, B., and Spy-Anderson, F.L., 2003, Architecture of an active mud-rich turbidite system: the Zaire Fan (Congo-Angola margin southeast Atlantic), results from ZaïAngo 1 and 2 cruises: American Association of Petroleum Geologists, Bulletin, v. 87, p. 1145-1168.

Dupré, B., Gaillardet, J., Rousseau, D., And Allègre, C.J., 1996, Major and trace elements of river-borne material: the Congo Basin: Geochimica et Cosmochimica Acta, v. 60, p. 1301-1321.

Dutta, P.K., Zhou, Z., And Dos Santos, P.R., 1993, A theoretical study of mineralogical maturation of eolian sand, in Johnsson, M., and Basu, A., eds., Processes Controlling the Composition of Clastic Sediments: Geological Society of America, Special Paper 284, p. 203-209.

EISMA, D., AND KALF, J., 1984, Dispersal of Zaire River suspended matter in the estuary and the Angola Basin: Netherlands Journal of Sea Research, v. 17, p. 385-411.

Feakins, S.J., Liddy, H.M., Tauxe, L., Galy, V., Feng, X., Tierney, J.E., Miao, Y., and WARNY, S., 2020, Miocene C4 grassland expansion as recorded by the Indus Fan: Paleoceanography and Paleoclimatology, v. 35, doi:10.1029/2020PA003856.

Ferry, J.N., Babonneau, N., Mulder, T., Parize, O., and Raillard, S., 2004, Morphogenesis of Congo submarine canyon and valley: implications about the theories of the canyons formation: Geodinamica Acta, v. 17, p. 241-251.

Fierens, R., Toucanne, S., Droz, L., Jouet, G., Raisson, F., Jorissen, E.L., Bayon, G., Giraudeau, J., and Jorry, S., 2020, Quaternary sediment dispersal in the Zambezi turbidite system (SW Indian Ocean): Marine Geology, v. 428, no. 106276, doi:10.1016/j. margeo.2020.106276.

FLÜGEL, T.J., ECKARdT, F.D., AND COTTERIL, F.P.D., 2015, The present-day drainage patterns of the Congo River system and their Neogene evolution, in de Wit, M.J., Guillocheau, F., and de Wit, M.J.C., eds., Geology and Resource Potential of the Congo Basin, Regional Geology Reviews: Berlin, Springer-Verlag, p. 315-337.

FolK, R.L., 1980, Petrology of Sedimentary Rocks: Austin, Hemphill Publishing, 184 p. Freeman, J.J., Wang, A., Kuebler, K.E., Jolliff, B.L., and Haskin, L.A., 2008, Characterization of natural feldspars by Raman spectroscopy for future planetary exploration: The Canadian Mineralogist, v. 46, p. 1477-1500.

GABriEL, K.R., 1971, The biplot graphic display of matrices with application to principal component analysis: Biometrika, v. 58, p. 453-467.

Gaillardet, J., Dupré, B., AND Allègre, C.J., 1995, A global geochemical mass budget applied to the Congo Basin rivers: erosion rates and continental crust composition: Geochimica et Cosmochimica Acta, v. 59, p. 3469-3485.

Galy, V., Eglinton, T., France-Lanord, C., and Sylva, S., 2011, The provenance of vegetation and environmental signatures encoded in vascular plant biomarkers carried by the Ganges-Brahmaputra rivers: Earth and Planetary Science Letters, v. 304, p. 1-12.

GARZANTI, E., 1986, Source rock versus sedimentary control on the mineralogy of deltaic volcanic arenites (Upper Triassic, northern Italy): Journal of Sedimentary Petrology, v. 56, p. 267-275.

GARZANTI, E., 2017, The maturity myth in sedimentology and provenance analysis: Journal of Sedimentary Research, v. 87, p. 353-365.

Garzanti, E., 2019, Petrographic classification of sand and sandstone: Earth-Science Reviews, v. 192, p. 545-563. 
Garzanti, E., And Andò, S., 2019, Heavy Minerals for Junior Woodchucks: Minerals, v. 9 , doi:10.3390/min9030148.

Garzanti, E., Vezzoli, G., Ando, S., and Castiglioni, G., 2001, Petrology of rifted-margin sand (Red Sea and Gulf of Aden, Yemen): The Journal of Geology, v. 109, p. 277-297.

Garzanti, E., Andò, S., And Vezzoli, G., 2008, Settling equivalence of detrital minerals and grain-size dependence of sediment composition: Earth and Planetary Science Letters, v. 273, p. 138-151.

Garzanti, E., Andò, S., and Vezzoli G., 2009, Grain-size dependence of sediment composition and environmental bias in provenance studies: Earth and Planetary Science Letters, v. 277, p. $422-432$.

Garzanti, E., Andò, S., France-Lanord, C., Vezzoli, G., and Najman, Y., 2010 Mineralogical and chemical variability of fluvial sediments. 1. Bedload sand (GangaBrahmaputra, Bangladesh): Earth and Planetary Science Letters, v. 299, p. 368-381.

Garzanti, E., Andò, S., France-Lanord, C., Galy, V., Censi, P., and Vignola, P., 2011 Mineralogical and chemical variability of fluvial sediments. 2. Suspended-load silt (Ganga-Brahmaputra, Bangladesh): Earth and Planetary Science Letters, v. 302, p. 107120.

Garzanti, E., Andò, S., Vezzoli, G., Lustrino, M., Boni, M., and Vermeesch, P., 2012a, Petrology of the Namib Sand Sea: long-distance transport and compositional variability in the wind-displaced Orange Delta: Earth-Science Reviews, v. 112, p. 173-189.

Garzanti, E., Resentini, A., Vezzoli, G., Andò, S., Malusà, M., and Padoan, M., 2012b, Forward compositional modelling of Alpine orogenic sediments: Sedimentary Geology, v. 280 , p. $149-164$.

Garzanti, E., Padoan, M., Andò, S., Resentini, A., Vezzoli, G., and Lustrino, M., 2013a, Weathering and relative durability of detrital minerals in equatorial climate: sand petrology and geochemistry in the East African Rift: The Journal of Geology, v. 121, p. $547-580$

Garzanti, E., Padoan, M., Setti, M., Peruta, L., Najman, Y., and Villa, I.M., 2013b, Weathering geochemistry and Sr-Nd fingerprints of equatorial upper Nile and Congo muds: Geochemistry, Geophysics, Geosystems, v. 14, p. 292-316.

Garzanti, E., Vermeesch, P., Padoan, M., Resentini, A., Vezzoli, G., and Andò, S., 2014a, Provenance of passive-margin sand (Southern Africa): The Journal of Geology, v. 122, p. $17-42$.

Garzanti, E., Padoan, M., Setti, M., López-Galindo, A., and Villa, I.M., 2014b, Provenance versus weathering control on the composition of tropical river mud (southern Africa): Chemical Geology, v. 366, p. 61-74

Garzanti, E., Vermeesch, P., Andò, S., Lustrino, M., Padoan, M., and Vezzoli, G., 2014c, Ultra-long-distance littoral transport of Orange sand and provenance of the Skeleton Coast Erg (Namibia): Marine Geology, v. 357, p. 25-36

Garzanti, E., Andò, S., Padoan, M., Vezzoli, G., And El Kammar, A., 2015a, The modern Nile sediment system: processes and products: Quaternary Science Reviews, v. 130, p $9-56$

Garzanti, E., Resentini, A., Andò, S., Vezzoli, G., Pereira, A., and Vermeesch, P., 2015b, Physical controls on sand composition and relative durability of detrital minerals during ultra-long-distance littoral and aeolian transport (Namibia and southern Angola): Sedimentology, v. 62, p. 971-996.

Garzanti, E., Dinis, P., Vermeesch, P., Andò, S., Hahn, A., Huvi, J., Limonta, M., Padoan, M., Resentini, A., Rittner, M., And Vezzoli, G., 2018a, Dynamic uplift, recycling, and climate control on the petrology of passive-margin sand (Angola): Sedimentary Geology, v. 375 , p. $86-104$

Garzanti, E., Dinis, P., Vermeesch, P., Andò, S., Hahn, A., Huvi, J., Limonta, M., Padoan, M., Resentini, A., Rittner, M., and Vezzoli, G., 2018b, Sedimentary processes controlling ultralong cells of littoral transport: placer formation and termination of the Orange sand highway in southern Angola: Sedimentology, v. 65, p. 431-460.

Garzanti, E., Vermeesch, P., Andò, S., Botti, E., Limonta, M., Vezzoli, G., Dinis, P., Hahn, A., Baudet, D., De Grave, J., and Kitambala Yaya, N. 2019a, Congo River sand and the equatorial quartz factory: Earth-Science Reviews, v. 197, no. 102918, doi:10.101 6/j.earscirev.2019.102918.

Garzanti, E., Andò, S., France-Lanord, C., Limonta, M., Borromeo, L., and Vezzoli, G., 2019b, Provenance of Bengal Shelf Sediments. 2. Petrology of sand: Minerals, v. 9, no. 642, doi: 10.3390/min9100642.

Garzanti, E., Andò, S., and Vezzoli, G., 2020, Provenance of Cenozoic Indus Fan sediments (IODP Sites U1456 and U1457): Journal of Sedimentary Research, v. 90, p. $1114-1127$

Giresse, P., 2005, Mesozoic-Cenozoic history of the Congo Basin: Journal of African Earth Sciences, v. 43, p. 301-315.

Goldich, S.S., 1938, A study in rock-weathering: The Journal of Geology, v. 46, p. 17-58 Goudie, A.S., 2005, The drainage of Africa since the Cretaceous: Geomorphology, v. 67, p 437-456.

Graham, W.A.P., 1930, A textural and petrographic study of the Cambrian sandstones of Minnesota: The Journal of Geology, v. 38, p. 696-716.

HaY, W.W., 1998, Detrital sediment fluxes from continents to oceans: Chemical Geology, v. 145 , p. $287-323$

HAYES, J.R., 1962, Quartz and feldspar content in South Platte, Platte, and Missouri River sands: Journal of Sedimentary Petrology, v. 32, p. 793-800.

Heezen, B.C., Menzies, R.J., Schneider, E.D., Ewing, W.M., and Granelli, N.C.L., 1964, Congo Submarine Canyon: American Association of Petroleum Geologists, Bulletin, v. 48 , p. $1126-1149$.
Hein, C.J., Galy, V., Galy, A., France-Lanord, C., Kudrass, H., and Schwenk, T., 2017, Post-glacial climate forcing of surface processes in the Ganges-Brahmaputra river basin and implications for carbon sequestration: Earth and Planetary Science Letters, v. 478, p. 89-101.

Hessler, A.M., and Fildani, A., 2019, Deep-sea fans: tapping into Earth's changing landscapes: Journal of Sedimentary Research, v. 89, p. 1171-1179.

Hessler, A.M., Covault, J., Stockli, D.F., and Fildani, A., 2018, Late Cenozoic cooling favored glacial over tectonic controls on sediment supply to the western Gulf of Mexico: Geology, v. 46, p. 995-998, doi.org/10.1130/G45528.1.

HuBERT, J.F., 1962, A zircon-tourmaline-rutile maturity index and the interdependence of the composition of heavy mineral assemblages with the gross composition and texture of sandstones: Journal of Sedimentary Petrology, v. 32, p. 440-450.

InGERsoll, R.V., AND SuczeK, C.A., 1979, Petrology and provenance of Neogene sand from Nicobar and Bengal fans, DSDP sites 211 and 218: Journal of Sedimentary Petrology, v. 49 , p. $1217-1228$.

Ingersoll, R.V., Bullard, T.F., Ford, R.L., Grimm, J.P., Pickle, J.D., and Sares, S.W., 1984, The effect of grain size on detrital modes: a test of the Gazzi-Dickinson pointcounting method: Journal of Sedimentary Petrology, v. 54, p. 103-116.

KaRner, G.D., AND Driscoll, N.W., 1999, Tectonic and stratigraphic development of the West African and eastern Brazilian margins: insights from quantitative basin modelling, in Cameron, N.R., Bate, R.H., and Clure, V.S., eds., The Oil and Gas Habitats of the South Atlantic: Geological Society of London, Special Publication 153, p. 11-40.

Laraque, A., Bricquet, J.P., Pandi, A., and Olivry, J.C., 2009, A review of material transport by the Congo River and its tributaries: Hydrological Processes, v. 23, p. 3216 3224 .

Lavier, L.L., Steckler, M.S., and Brigaud, F., 2001, Climatic and tectonic control on the Cenozoic evolution of the West African margin: Marine Geology, v. 178, p. 63-80.

Leturmy, P., Lucazeau, F., and Brigaud, F., 2003, Dynamic interactions between the Gulf of Guinea passive margin and the Congo River drainage basin: 1. Morphology and mass balance: Journal of Geophysical Research, Solid Earth, v. 108(B8), no. 2383, doi:10.102 9/2002JB001927.

Linol, B., de Wit, M.J., Guillocheau, F., DE Wit, M.C.J., AnKa, Z., And Colin, J.P., 2015, Formation and collapse of the Kalahari Duricrust ("African Surface") across the Congo Basin, with implications for changes in rates of Cenozoic off-shore sedimentation, in de Wit, M.J., Guillocheau, F., and de Wit, M.J.C., eds., Geology and Resource Potential of the Congo Basin: Regional Geology Reviews: Berlin, Springer-Verlag, p. 193-210.

Lucazeau, F., Brigaud, F., and Leturmy, P., 2003, Dynamic interactions between the Gulf of Guinea passive margin and the Congo River drainage basin: 2. Isostasy and uplift: Journal of Geophysical Research, Solid Earth, v. 108(B8), no. 2384, doi:10.1029/2002 JB001928.

Malusà, M.G., Carter, A., Limoncelli, M., Villa, I.M., and Garzanti, E., 2013, Bias in detrital zircon geochronology and thermochronometry: Chemical Geology, v. 359, p. 90 107

Marsaglia, K.M., and Ingersoll, R.V., 1992, Compositional trends in arc-related, deepmarine sand and sandstone: a reassessment of magmatic-arc provenance: Geological Society of America, Bulletin, v. 104, p. 1637-1649.

Marsaglia, K.M., Barragan, J.G.C., Padilla, I., and Milliken, K.L., 1996, Evolution of the Iberian passive margin as reflected in sand provenance, in Whitmarsh, R.B., Sawyer, D.S., Klaus, A., and Masson, D.G., eds., Proceedings of the Ocean Drilling Program, Scientific Results, v. 149 , p. 269-280.

Marsset, T., ANd Droz, L., 2010, REPREZAI_LEG1 cruise, RV Pourquoi Pas?, doi:10.1 $7600 / 10030170$

Marsset, T., Droz, L., Dennielou, B., And Pichon, E., 2009, Cycles in the architecture of the Quaternary Zaire turbidite system: a possible link with climate, in Kneller, B. Martinsen, O.J., and McCaffrey, W., eds., External Controls on Deep-Water Depositional Systems: SEPM, Special Publication 92, p. 89-106.

McBride, E.F., Abel-WahaB, A., AND McGilvery, T.A., 1996, Loss of sand-size feldspar and rock fragments along the South Texas Barrier Island, USA: Sedimentary Geology, y. 107 , p. $37-44$.

McGinnis, J.P., Driscoll, N.W., Karner, G.D., Brumbaugh, W.D., and Cameron, N., 1993 Flexural response of passive margins to deep-sea erosion and slope retreat: implications for relative sea-level change: Geology, v. 21, p. 893-896.

Mclennan, S.M., Taylor, S.R., McCulloch, M.T., and Maynard, J.B., 1990, Geochemical and Nd-Sr isotopic composition of deep-sea turbidites: crustal evolution and plate tectonic associations: Geochimica et Cosmochimica Acta, v. 54, p. 2015-2050. McLennan, S.M., Hemming, S., McDaniel, D.K., and Hanson, G.N., 1993, Geochemical approaches to sedimentation, provenance, and tectonics, in Johnsson, M., and Basu, A., eds., Processes Controlling the Composition of Clastic Sediments: Geological Society of America, Special Paper 284, p. 21-40.

Milliman, J.D., And Farnsworth, K.L., 2013, River discharge to the coastal ocean: a global synthesis: Cambridge, UK, Cambridge University Press, 383 p.

Nesbitt, H.W., And Young, G.M., 1996, Petrogenesis of sediments in the absence of chemical weathering: effects of abrasion and sorting on bulk composition and mineralogy: Sedimentology, v. 43, p. 341-358.

Nesbitt, H.W., Fedo, C.M., And Young, G.M., 1997, Quartz and feldspar stability, steady and non-steady-state weathering, and petrogenesis of siliciclastic sands and muds: The Journal of Geology, v. 105, p. 173-192. 
Nuome, M.S., AND De Wit, M.J., 2014, The Cameroon Line: analysis of an intraplate magmatic province transecting both oceanic and continental lithospheres: constraints, controversies and models: Earth-Science Reviews, v. 139, p. 168-194.

Oberg, K., Shelton, J.M., Gardiner, N., And Jackson, P.R., 2009, Discharge and other hydraulic measurements for characterizing the hydraulics of lower Congo River: International Association for Hydraulic Research Congress, Proceedings, v. 33, 8 p.

Odom, I.E., Doe, T.W., and DotT, R.H., 1976, Nature of feldspar-grain size relations in some quartz-rich sandstones: Journal of Sedimentary Petrology, v. 46, p. 862-870

Padoan, M., Garzanti, E., Harlavan, Y., and Villa, I.M., 2011, Tracing Nile sediment sources by $\mathrm{Sr}$ and $\mathrm{Nd}$ isotope signatures (Uganda, Ethiopia, Sudan): Geochimica et Cosmochimica Acta, v. 75, p. 3627-3644.

Peters, C.R., And O'Brien, E.M., 2001, Palaeo-lake Congo: implications for Africa's late Cenozoic climate: some unanswered questions, in Heine, K., and Runge, J., eds., Palaeoecology of Africa and the Surrounding Islands: Boca Raton, CRC Press, 25th Inqua Conference, Durban, South Africa, Proceedings, v. 27, p. 11-18.

Pickering, K., Carter, A., Andò, S., Garzanti, E., Limonta, M., Vezzoli, G., and Milliken, K.L., 2020, Deciphering relationships between the Nicobar and Benga submarine fans, Indian Ocean: Earth and Planetary Science Letters, v. 544, no. 16329, doi:10.1016/j.eps1.2020.116329.

Picot, M., Marsset, T., Droz, L., Dennielou, B., Baudin, F., Hermoso, M., De Rafélis, M., Sionneau, T., Cremer, M., Laurent, D., and Bez, M., 2019, Monsoon control on channe avulsions in the Late Quaternary Congo Fan: Quaternary Science Reviews, v. 204, p. 149-171.

Pollack, J.M., 1961, Significance of compositional and textural properties of South Canadian River channel sands, New Mexico, Texas, and Oklahoma: Journal of Sedimentary Petrology, v. 31, p. 15-37.

Rabouille, C., 2011, CONGOLOBE cruise, RV Pourquoi Pas?, doi:10.17600/11030170.

Rabouille, C., Dennielou, B., Baudin, F., Raimonet, M., Droz, L., Khripounoff, A., Martinez, P., Mejanelle, L., Michalopoulos, P., Pastor, L., Pruski, A., Ragueneau, O., Reyss, J.-L., Ruffine, L., Schnyder, J., Stetten, E., TAillefert, M., Tourolle, J., And Olu, H., 2019, Carbon and silica megasink in deep-sea sediments of the Congo terminal lobes: Quaternary Science Reviews, v. 222, no. 105854, doi:10.1016/j.quascirev.2019.0 7.036 .

Resentini, A., Goren, L., Castelltort, S., and Garzanti, E., 2017, Partitioning sediment flux by provenance and tracing erosion patterns in Taiwan: Journal of Geophysica Research, Earth Surface, v. 122, p. 1430-1454.

Resentini, A., Andò, S., And Garzanti, E., 2018, Quantifying roundness of detrital minerals by image analysis: sediment transport, shape effects, and provenance implications: Journal of Sedimentary Research, v. 88, p. 276-289.

Resentini, A., Andò, S., Garzanti, E., Malusà, M.G., Pastore, G., Vermeesch, P., Chanvry, E., AND Dall'Asta, M., 2020, Zircon as a provenance tracer: coupling Raman spectroscopy and U-Pb geochronology in source-to-sink studies: Chemical Geology, v. 555 , no 119828

Revel, M., Colin, C., Bernasconi, S., Combourieu-Nebout, N., Ducassou, E., Grousset, F.E., Rolland, Y., Migeon, S., Bosch, D., Brunet, P., Zhao, Y., and Mascle, J., 2014 21,000 years of Ethiopian African monsoon variability recorded in sediments of the western Nile deep-sea fan: Regional Environmental Change, v. 14, p. 1685-1696.

Rubey, W.W., 1933, The size-distribution of heavy minerals within a water-laid sandstone Journal of Sedimentary Petrology, v. 3, p. 3-29.

Rudnick, R.L., And GaO, S., 2003, Composition of the continental crust, in Rudnick, R.L., Holland, H.D., and Turekian, K., eds., Treatise on Geochemistry, 3, The Crust: Oxford, Elsevier Pergamon, p. 1-64.

Runge, J., 2007, The Congo River, central Africa, in Gupta, A., ed., Large Rivers: Geomorphology and Management: New York, Wiley, p. 293-309.

Russell, R.D., 1937, Mineral composition of Mississippi River sands: Geological Society of America, Bulletin, v. 48, p. 1307-1348.

SAVOYE, B., 1998, ZAIANGO1 cruise, RV L'Atalante, doi:10.17600/98010100.

SAVOYe, B., And Ondréas, H., 2000, ZAIANGOROV cruise, RV L'Atalante, doi:10.1 $7600 / 10100$
Savoye, B., and Cochonat, P., et AL., 2000, Structure et évolution récente de l'éventail turbiditique du Zaïre: premiers résultats scientifiques des missions d'exploration Zaïango1\&2 (marge Congo-Angola): Comptes Rendus de l'Académie des Sciences, Series IIA, Earth and Planetary Science, v. 331, p. 211-220.

Savoye, B., Babonneau, N., Dennielou, B., and Bez, M., 2009, Geological overview of the Angola-Congo margin, the Congo deep-sea fan and its submarine valleys: Deep Sea Research, Part II: Topical Studies in Oceanography, v. 56, p. 2169-2182.

Schefuß, E., Eglinton, T.I., Spencer-Jones, C.L., Rullkötter, J., De Pol-Holz, R., Talbot, H.M., Grootes, P.M., AND Schneider, R.R., 2016, Hydrologic control of carbon cycling and aged carbon discharge in the Congo River basin: Nature Geoscience, v. 9, p. 687690

Séranne, M., AND ANKA, Z., 2005, South Atlantic continental margins of Africa: a comparison of the tectonic vs climate interplay on the evolution of equatorial west Africa and SW Africa margins: Journal of African Earth Sciences, v. 43, p. 283-300.

Shapiro, S.A., Marsaglia, K.M., and Carter, L., 2007, The petrology and provenance of sand in the Bounty submarine fan, New Zealand, in Arribas, J., Critelli, S., and Johnsson, M.J., eds., Sedimentary Provenance and Petrogenesis: Perspectives from Petrography and Geochemistry: Geological Society of America, Special Paper 420, p. 277-296, doi: $10.1130 / 2006.2420(17)$.

SHEPARD, F.P., AND EMERY, K.O., 1973, Congo submarine canyon and fan valley: American Association of Petroleum Geologists, Bulletin, v. 57, p. 1679-1691.

Singh, S.K., And France-Lanord, C., 2002, Tracing the distribution of erosion in the Brahmaputra watershed from isotopic compositions of stream sediments: Earth and Planetary Science Letters, v. 202, p. 645-662.

Tanaka, T., Togashi, S., Kamioka, H., Amakama, H., Kagami, H., Hamamoto, T., Yuhara, M., Orihashi, Y., Yoneda, S., Shimizu, H., Kunimaru, T., Takahashi, K., Yanagi, T., Nakano, T., Fujimaki, H., Shinjo, R., Asahara, Y., Tanimizu, M., and Dragusanu, C., 2000, JNdi-1: a neodymium isotopic reference in consistency with La Jolla neodymium: Chemical Geology, v. 168 , p. $279-281$.

TAYlor, S.R., And McLennan, S.M., 1995, The geochemical evolution of the continental crust: Reviews of Geophysics, v. 33, p. 241-265.

Thayer, P.A., Roberts, H.H., Bouma, A.H., and Coleman, J.M., 1986, Sedimentology and petrology of Mississippi Fan depositional environments, in Bouma, A.H., Coleman, J.M., Meyer, A.W., et al., eds., Initial Reports of the Deep-Sea Drilling Project, v. 96, p. 489503 .

Uenzelmann-Neben, G., 1998, Neogene sedimentation history of the Congo Fan: Marine and Petroleum Geology, v. 15, p. 635-650.

Von Eynatten, H., Tolosana-Delgado, R., and Karius, V., 2012, Sediment generation in modern glacial settings: grain-size and source-rock control on sediment composition: Sedimentary Geology, v. 280, p. 80-92.

Von Eynatten, H., Tolosana-Delgado, R., Karius, V., Bachmann, K., and Caracciolo, L., 2016, Sediment generation in humid Mediterranean setting: grain-size and source-rock control on sediment geochemistry and mineralogy (Sila Massif, Calabria): Sedimentary Geology, v. 336, p. 68-80.

Wagner, T., Kallweit, W., Talbot, H.M., Mollenhauer, G., Boom, A., and Zabel, M., 2014, Microbial biomarkers support organic carbon transport from methane-rich Amazon wetlands to the shelf and deep-sea fan during recent and glacial climate conditions: Organic Geochemistry, v. 67, p. 85-98.

Weijers, J.W., Schouten, S., Schefuß, E., Schneider, R.R., and Damste, J.S.S., 2009, Disentangling marine, soil and plant organic carbon contributions to continental margin sediments: a multi-proxy approach in a 20,000-year sediment record from the Congo deep-sea fan: Geochimica et Cosmochimica Acta, v. 73, p. 119-132.

Whitmore, G.P., Crook, K.A., And Johnson, D.P., 2004, Grain size control of mineralogy and geochemistry in modern river sediment, New Guinea collision, Papua New Guinea: Sedimentary Geology, v. 171, p. 129-157.

Whitney, D.L., Broz, M., AND CooK, R.F., 2007, Hardness, toughness, and modulus of some common metamorphic minerals: American Mineralogist, v. 92, p. 281-288.

Received 13 June 2020; accepted 26 February 2021. 